\title{
Use of Current Educational Technology in Science Education: A Scoping Review
}

\begin{tabular}{|c|c|}
\hline \multicolumn{2}{|c|}{ Fatih Saltan ${ }^{a^{*}}$, Tuğçe Türkyılmaz ${ }^{a}$, Caner Karaçaltı ${ }^{a}$, Kemal Bilir ${ }^{\text {a }}$} \\
\hline Article Info & Abstract \\
\hline DOI: 10.14812/cuefd.304015 & $\begin{array}{l}\text { The study aims to identify the educational technology used in elementary science and } \\
\text { technology courses, and to determine their advantages and limitations. Based on this }\end{array}$ \\
\hline Article history: & aim, 393 thesis and dissertations related with the usage of educational technology in \\
\hline Received $\quad 05.04 .2017$ & science and technology courses published between 2012 and 2016 in national thesis \\
\hline Revised $\quad 15.02 .2018$ & center, which is a service of Publication and documentation department of Higher \\
\hline Accepted $\quad 12.04 .2018$ & Education Council, were examined. This investigation was conducted through Scoping \\
\hline $\begin{array}{l}\text { Keywords: } \\
\text { Academic success, } \\
\text { Student engagement, } \\
\text { Student gains, } \\
\text { Structural equation modeling, } \\
\text { College students. }\end{array}$ & $\begin{array}{l}\text { procedure followed to use this method is the framework proposed by Arksey and } \\
\text { O'Malley (2005). PRISMA (2009) model was used during the thesis selection process. } \\
\text { According to the results, significant differences were observed in } 91 \% \text { of the thesis } \\
\text { listed for academic achievement; in } 78 \% \text { of the thesis listed for the effect on the } \\
\text { attitude toward science and technology course; and in } 77 \% \text { of the thesis listed for the } \\
\text { effect on knowledge persistence. In the thesis and dissertations listed in the current } \\
\text { study, quasi-experimental method was mainly used (89\%) and mixed-methods were } \\
\text { leastwise used. In these thesis and dissertations, achievements and persistence tests, } \\
\text { attitude and motivation scales, and open-ended questions were used as the data } \\
\text { collection instrument. }\end{array}$ \\
\hline
\end{tabular}

\begin{tabular}{ll}
\hline \multicolumn{1}{c}{ Güncel Eğitim Teknolojilerinin Fen Eğitiminde Kullanılması: Tarama } \\
Çalışması
\end{tabular}

*Author: fsaltan@gmail.com 


\section{Introduction}

The use of contemporary and cutting-edge Information and Communication Technologies (ICTs) by the teachers in developed countries is amongst one of the proxy factors for the success of education. In this regard, teachers' competencies and qualifications have a great importance (Bal \& Karademir, 2013). Teachers' competencies were first investigated by pedagogue Shulman. According to Shulman (1986) pedagogical content knowledge (PCK) is one of the significant factors for understanding a teacher's level of proficiency. PCK is a combination of a teacher's use of both content knowledge (CK) and pedagogical knowledge (PK). The development of technology after 1980s and the prevalence of the use of technology in daily lives also enabled the use of them for educational purposes. Mishra and Koehler (2009) emphasized the influence of technology on teachers' competencies and proposed technological pedagogical content knowledge (TPCK). This framework combines content knowledge (CK), pedagogical knowledge (PK) with technological knowledge (TK) for a more effective teaching-learning processes. According to this model, teachers' technological competency is not complementary without other specific knowledge spaces. For a more effective instruction to take place, content, pedagogy and technology should be used together in accordance with each other.

Technology is being utilized for supplementing teaching-learning processes across diverse disciplines including but not limited with science education, mathematics education or literature education. Amongst those, science education differs from other disciplines with respect to the use of technology (Taşşı, Yaman, \& Soran, 2010). Through the regulations of the Ministry of National Education in 2004-2005 the name of the course "Science Education" was replaced with "Science \& Technology Education" which resulted in an integration of educational technologies into science education. When the content of science education is examined with respect to curriculum it is seen that there are abstract concepts with a dynamic structure (Kahyaoğlu, 2011). For this reason, the expectations for a more technology supported instruction increased. Through the use of rich materials including animations, simulations, podcasts or videos learning environments become richer with respect to media used for teaching-learning processes. The use of rich media enables students to activate different sensory systems (Kahyaoğlu, 2011). Other than the use of such rich media, the use of educational technologies with contemporary resources available and accessible through the internet, CDs, electronic documents, digital worksheets or online learning environments where reciprocal information exchange takes place provide different opportunities as a learning space (Taşçı, Yaman, \& Soran, 2010). These opportunities have the potential of increasing students' attention towards the lessons and make those lesson more understandable. Jimoyiannis and Komis (2001) stated that integrating science education courses with educational technologies makes it easier to establish the learning objectives, enhances students' capabilities that they should have within science education courses and saves time during the instruction. In other words, the use of educational technologies in science education courses provides an alternative to overcome the barrier of explaining concepts and content of science along with supporting the constructivist way of knowledge building. The new curriculum of Science and Technology course underpins the constructivist approach. The role of a teacher in student-centered classrooms is not the one instructing the prescribed knowledge but to guide students for constructing their own knowledge. This approach enables students to experience learning processes by actively involving into learning processes (Erdoğan, 2007). Furthermore, "the knowledge retention is satisfied as students get involved into learning processes" (Erdoğan, 2007).

Teachers are one of the most important stakeholders of technology integration into science and technology courses (Kahyaoğlu,2011). Science and technology is amongst one of the most difficult courses and using the current and cutting edge technologies along with qualified teachers will enable to overcome that difficulty. In this regard, it is important for teachers to have the required skills and competencies for technology integration into teaching-learning processes. Hence, it gets prominent to investigate the current state of the art for the use of educational technologies, its benefits and barriers in science and technology education. From this perspective, this study will illustrate the current use of educational technologies in science and technology courses along with its benefits and barriers encountered during the process. Furthermore, it will enables teachers and researchers to draw a picture of the literature concerning the use of educational technologies in science and technology courses. There are numerous studies that focused on the use of educational technologies, but there is a constant need for renewing those studies as the related 
studies increase day by day. For instance, Karamustafaoğlu (2015) conducted a study on the trends in science and technology education and concluded eight different themes. Along with carrying out literature reviews based on research articles, there is also a need for investigating thesis and dissertations with respect to the use of educational technologies in science and technology courses.

This study primarily aims at investigating two perspectives with respect to use of educational technologies in Science and Technology courses at the secondary school level. First, the study examines which of the educational technologies are being utilized. Second, the study also investigates the benefits and barriers of using educational technologies in those courses. For this reason, thesis and dissertations concerning the use of educational technologies in Science and Technology Courses published between 2012 and 2016 were included to answer the research questions.

\section{Method}

The study investigated thesis and dissertations on the use of educational technologies in Science and Technology courses in Turkey. The method of scoping review was underpinned to answer the research questions. The stages of the scoping review were carried out as proposed by Arksey and O'Malley (2005). These stages are (1) determining research questions, (2) identifying relevant studies, (3) selecting studies, (4) charting the studies, and (5) summarizing and reporting the results. This five-stage framework was followed to be able to answer the research questions.

\section{Determining Research Questions}

The primary focus of the scoping review was the investigation of the use of educational technologies, specifically in the context of Science and Technology courses. To be able to draw a holistic picture of the current state of the art concerning the use of educational technologies in Science and Technology courses, following research questions were posed:

1. Does the use of educational technologies in Science and Technology courses influence the academic achievement? If so, how?

2. Does the use of educational technologies in Science and Technology courses influence the attitudes toward the courses? If so, how?

3. Does the use of Educational Technologies in Science and Technology courses influence the knowledge retention? If so, how?

4. Does the use of Educational Technologies in Science and Technology courses influence the success of scientific process? If so, how?

5. Which of the research methodologies were used in thesis and dissertations?

6. Which of the data collection tools were used in thesis and dissertations?

\section{Identifying Relevant Studies}

The search term 'Science and Technology Course' was determined to be able to reach broad range of thesis and dissertations on the use of educational technologies in Science and Technology courses in Turkey. The reason for the use of such a broad search term was to draw diverse examples of related thesis and dissertations. Afterwards, numerous inclusion and exclusion criteria were determined for the selection of appropriate studies. These criteria were determined based on the studies that were reached through the use of search term; that is, 'Science and Technology Course'. These criteria were illustrated in Table 1. To draw the current situation of the use of educational technologies in thesis and dissertations, the last five years (2012-2016) was determined as a basis for publication date. The database of Council of Higher Education Thesis Center was utilized to reach the relevant studies. The primary reason for selecting this database was due to fact that it contains thesis and dissertations carried out in Turkey. 
Table 1.

Inclusion and exclusion criteria

\begin{tabular}{|c|c|c|}
\hline Criteria & Inclusion & Exclusion \\
\hline Time period & The last five years (2012-2016) & $\begin{array}{l}\text { Thesis and dissertations published } \\
\text { outside of these dates }\end{array}$ \\
\hline Study focus & $\begin{array}{l}\text { Formal education context (Secondary } \\
\text { school level) }\end{array}$ & $\begin{array}{l}\text { Studies included informal } \\
\text { educational context }\end{array}$ \\
\hline \multirow[t]{2}{*}{ Focus of literature } & $\begin{array}{l}\text { Activities in formal education context } \\
\text { and results of those activities (e.g. } \\
\text { academic achievement, knowledge } \\
\text { retention, scientific process abilities, } \\
\text { attitude) }\end{array}$ & $\begin{array}{l}\text { The use of educational } \\
\text { technologies outside of Science } \\
\text { and Technology course, irrelevant } \\
\text { Science and Technology courses }\end{array}$ \\
\hline & $\begin{array}{l}\text { Thesis and dissertations carried out } \\
\text { between 2012-2016 }\end{array}$ & \\
\hline Sample & $\begin{array}{l}\text { 6th grade science and technology } \\
\text { course, the use of educational } \\
\text { technologies in "granular structure of } \\
\text { particulars" and its influence of } \\
\text { academic achievement and } \\
\text { knowledge retention }\end{array}$ & $\begin{array}{l}\text { 7th grade science and Technology } \\
\text { course, the use of Educational } \\
\text { Technologies in "symmetry" and } \\
\text { its influences on academic } \\
\text { achievement and knowledge } \\
\text { retention }\end{array}$ \\
\hline
\end{tabular}

\section{Selecting Studies}

The key term 'Science and Technology Course' was used for the selection of thesis and dissertations on the database of Council of Higher Education Thesis Center. The search was initiated on December, 06, 2016. The search was resulted in 49 dissertations and 344 thesis. Based on the inclusion and exclusion criteria titles and Abstracts of the Studies were examined. The determination of the relevant thesis and dissertations were carried out based on the PRISMA (2009) model (Moher, Liberate, Tetzlaff, Altman, \& PRISMA Group, 2009). The process of selecting Studies was illustrated in Figure 2.

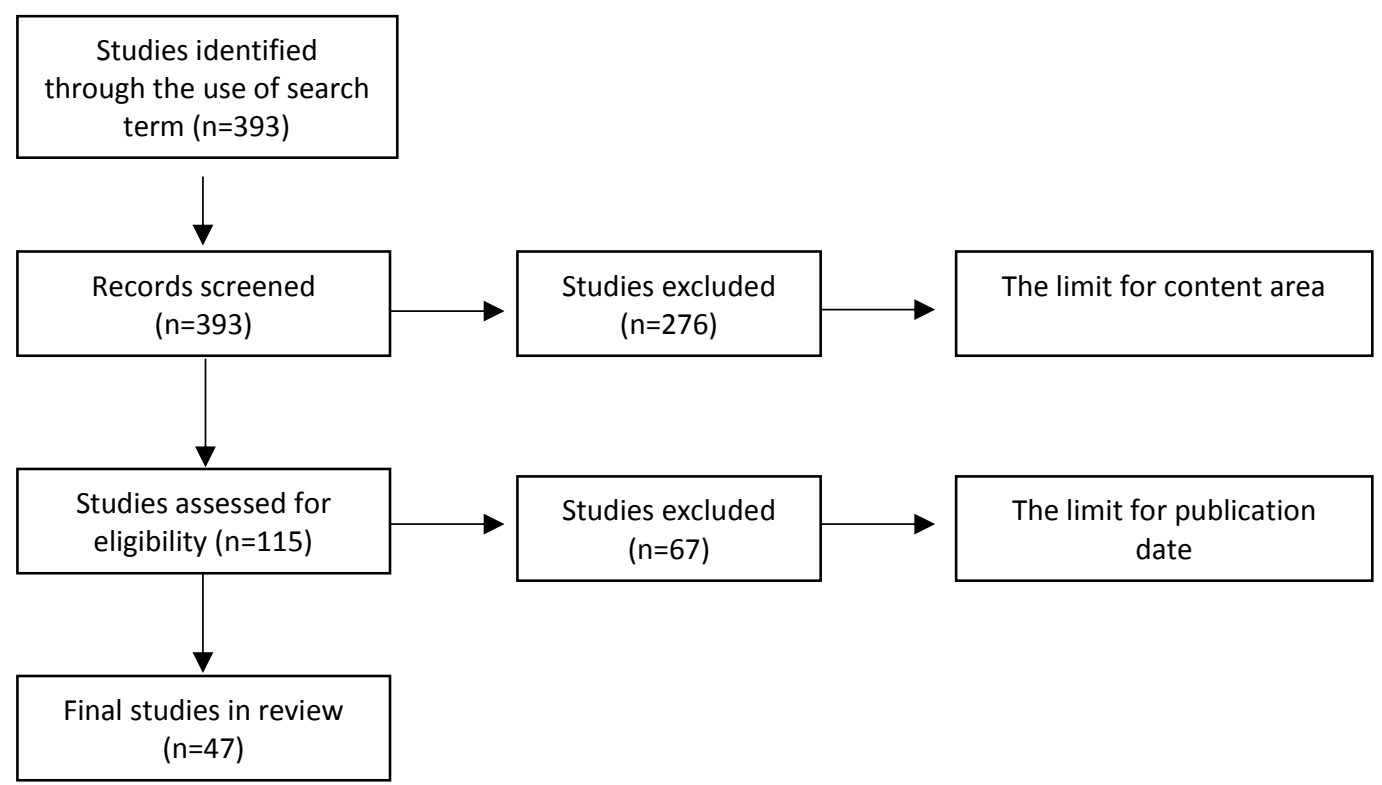

Figure 2. PRISMA flow diagram for the selection of thesis and dissertations 
Table 2.

Finding of the Thesis and Dissertations.

\begin{tabular}{|c|c|c|c|c|c|c|c|}
\hline Author & $\begin{array}{l}\text { Özdemir, A. M. } \\
\text { (2012) }\end{array}$ & $\begin{array}{l}\text { Sever, D. } \\
\text { (2012) }\end{array}$ & Güçlüer, E. (2012) & $\begin{array}{l}\text { Çeliker, H. D. } \\
\text { (2012) }\end{array}$ & $\begin{array}{l}\text { Daşdemir, i. } \\
\text { (2012) }\end{array}$ & Gürbüz, F. (2012) & Öztürk, N. (2013) \\
\hline Sample & $\begin{array}{l}\text { 5th grade / } 25 \\
\text { Student }\end{array}$ & $\begin{array}{l}\text { 7th grade / } 25 \\
\text { Student }\end{array}$ & $\begin{array}{l}\text { 7th grade / } 35 \\
\text { Student }\end{array}$ & 7th grade & $\begin{array}{l}\text { 8th grade / } 37 \\
\text { Student }\end{array}$ & $\begin{array}{l}\text { 6th grade / } 45 \\
\text { Student }\end{array}$ & 6th grade / 43 Student \\
\hline $\begin{array}{l}\text { Educational } \\
\text { Technology }\end{array}$ & $\begin{array}{l}\text { Conceptual } \\
\text { Change Texts ve } \\
\text { Concept Maps }\end{array}$ & $\begin{array}{l}\text { Research } \\
\text { Based } \\
\text { Learning } \\
\end{array}$ & $\begin{array}{l}\text { Activities } \\
\text { İmproving } \\
\text { Science Literacy }\end{array}$ & $\begin{array}{l}\text { Project Based } \\
\text { Learning }\end{array}$ & Animation & 7E Learning Model & 5E Learning Model \\
\hline $\begin{array}{l}\text { Dependent } \\
\text { Variable }\end{array}$ & $\begin{array}{l}\text { Academic } \\
\text { achievement } \\
\text { Attitude towards } \\
\text { Science and } \\
\text { Technology Lesson } \\
\text { Motivation }\end{array}$ & $\begin{array}{l}\text { Student } \\
\text { Resistance }\end{array}$ & $\begin{array}{l}\text { Academic } \\
\text { achievement } \\
\text { Attitude towards } \\
\text { Science and } \\
\text { Technology Lesson } \\
\text { Scientific Process } \\
\text { Skills }\end{array}$ & $\begin{array}{l}\text { Academic } \\
\text { achievement } \\
\text { Attitude towards } \\
\text { science and } \\
\text { technology } \\
\text { Creative Thinking }\end{array}$ & $\begin{array}{l}\text { Academic } \\
\text { achievement } \\
\text { Permanence } \\
\text { Scientific } \\
\text { process skills }\end{array}$ & $\begin{array}{l}\text { Academic } \\
\text { achievement } \\
\text { Permanence }\end{array}$ & $\begin{array}{l}\text { Academic achievement } \\
\text { Motivation towards learning } \\
\text { science } \\
\text { Attitude towards science and } \\
\text { technology lesson } \\
\text { Scientific process skills } \\
\text { Academic self-efficacy }\end{array}$ \\
\hline Results & $\begin{array}{l}\text { It has been observed } \\
\text { that the students' } \\
\text { achievements } \\
\text { increased but the } \\
\text { attitudes and } \\
\text { motivations towards } \\
\text { the lessons were not } \\
\text { affected in the } \\
\text { courses in which the } \\
\text { conceptual change } \\
\text { approach was } \\
\text { applied. }\end{array}$ & $\begin{array}{l}\text { It can be } \\
\text { stated inquiry- } \\
\text { based learning } \\
\text { approach used } \\
\text { in science and } \\
\text { technology } \\
\text { teaching has } \\
\text { positive effect } \\
\text { on student } \\
\text { resistance } \\
\text { behaviors. }\end{array}$ & $\begin{array}{l}\text { The academic } \\
\text { achievement of } \\
\text { students has had a } \\
\text { significant impact on } \\
\text { the attitudes } \\
\text { towards science and } \\
\text { technology and the } \\
\text { level of scientific } \\
\text { process skills. }\end{array}$ & $\begin{array}{l}\text { It has been found } \\
\text { that the use of } \\
\text { project-based } \\
\text { activities in } \\
\text { science and } \\
\text { technology } \\
\text { course has a } \\
\text { positive effect on } \\
\text { students' } \\
\text { academic success, } \\
\text { scientific } \\
\text { creativity and } \\
\text { attitudes towards } \\
\text { the course. }\end{array}$ & $\begin{array}{l}\text { Use of } \\
\text { animation in } \\
\text { Science and } \\
\text { Technology } \\
\text { lessons has a } \\
\text { statistically } \\
\text { significant } \\
\text { effect on } \\
\text { students' } \\
\text { academic } \\
\text { achievement, } \\
\text { retention of } \\
\text { knowledge } \\
\text { and scientific } \\
\text { process skills. }\end{array}$ & $\begin{array}{l}\text { It is found out that } \\
\text { materials based on } 7 E \\
\text { learning model } \\
\text { support significantly } \\
\text { students achievement } \\
\text { and permanence level. } \\
\text { In addition, according } \\
\text { to interview it is } \\
\text { identified that } \\
\text { students have positive } \\
\text { views. }\end{array}$ & $\begin{array}{l}\text { 7E learning model has been a } \\
\text { significant influence on students' } \\
\text { scientific process skills, academic } \\
\text { achievement, motivation for } \\
\text { learning science, self-efficacy } \\
\text { towards science and technology } \\
\text { course and attitude. }\end{array}$ \\
\hline Author & $\begin{array}{l}\text { Sünkür, M. Ö. } \\
\text { (2013) }\end{array}$ & $\begin{array}{l}\text { Çakar, E. } \\
\text { (2013) }\end{array}$ & Demirçalı, S. (2014) & Uyanık, G. (2014) & $\begin{array}{l}\text { Aşiroğlu, S. } \\
\text { (2014) }\end{array}$ & Parsa, M. K. (2016) & Yurt, Y. (2012) \\
\hline
\end{tabular}


Saltan, Türkyılmaz, Karaçaltı \& Kemal Bilir - Çukurova Üniversitesi Eğitim Fakültesi Dergisi, 47(1), 2018, 308-336

\begin{tabular}{|c|c|c|c|c|c|c|c|}
\hline Sample & $\begin{array}{l}\text { 7th grade / } 79 \\
\text { Student }\end{array}$ & $\begin{array}{l}\text { 7th grade / } 59 \\
\text { Student }\end{array}$ & $\begin{array}{l}\text { 7th grade / } 48 \\
\text { Student }\end{array}$ & $\begin{array}{l}\text { 4th grade / } 50 \\
\text { Student }\end{array}$ & $\begin{array}{l}\text { 5th grade / } 39 \\
\text { Student }\end{array}$ & $\begin{array}{l}\text { 8th grade / } 49 \\
\text { Student }\end{array}$ & 6th grade / 128 Student \\
\hline $\begin{array}{l}\text { Educational } \\
\text { Technology }\end{array}$ & $\begin{array}{l}\text { Reflective } \\
\text { Thinking by } \\
\text { Supported } \\
\text { Predict-Observe- } \\
\text { Explain Method }\end{array}$ & $\begin{array}{l}\text { Research } \\
\text { Based } \\
\text { Learning }\end{array}$ & $\begin{array}{l}\text { Science-Technology- } \\
\text { Society Approach } \\
\text { Teaching }\end{array}$ & $\begin{array}{l}\text { Conceptual } \\
\text { Change }\end{array}$ & $\begin{array}{l}\text { Active } \\
\text { Learning }\end{array}$ & $\begin{array}{l}\text { Collaborative Inquiry- } \\
\text { Based Learning }\end{array}$ & 5E Learning Model \\
\hline $\begin{array}{l}\text { Dependent } \\
\text { Variable }\end{array}$ & $\begin{array}{l}\text { Academic } \\
\text { achievement } \\
\text { Attitude to the } \\
\text { learning domain } \\
\text { Scientific process } \\
\text { skills } \\
\text { Academic risk- } \\
\text { taking }\end{array}$ & $\begin{array}{l}\text { Academic } \\
\text { achievement } \\
\text { Attitude } \\
\text { towards } \\
\text { Science and } \\
\text { Technology } \\
\text { Lesson } \\
\text { Concept } \\
\text { teaching } \\
\text { Metacognition } \\
\text { awareness }\end{array}$ & $\begin{array}{l}\text { Attitude towards } \\
\text { Science-Technology- } \\
\text { Society } \\
\text { Creativity } \\
\text { Scientific process } \\
\text { skills Applying } \\
\text { concepts skills }\end{array}$ & $\begin{array}{l}\text { Academic } \\
\text { achievement } \\
\text { Attitude towards } \\
\text { Science and } \\
\text { Technology Lesson- } \\
\text { Motivation } \\
\text { Motivation for } \\
\text { learning science } \\
\text { Misconception }\end{array}$ & $\begin{array}{l}\text { Academic } \\
\text { achievement } \\
\text { Permanence } \\
\text { Problem } \\
\text { solving ability }\end{array}$ & $\begin{array}{l}\text { Attitude towards } \\
\text { Science and } \\
\text { Technology Lesson } \\
\text { Creativity thinking } \\
\text { İnquiry learning }\end{array}$ & $\begin{array}{l}\text { Academic achievement } \\
\text { Attitude towards Science and } \\
\text { Technology Lesson }\end{array}$ \\
\hline Results & $\begin{array}{l}\text { The application } \\
\text { significantly } \\
\text { influenced the } \\
\text { academic } \\
\text { achievement of } \\
\text { students, } \\
\text { permanence of } \\
\text { information, } \\
\text { attitudes towards } \\
\text { the unit, scientific } \\
\text { process skills, and } \\
\text { academic risk } \\
\text { taking skills. }\end{array}$ & $\begin{array}{l}\text { Students' } \\
\text { achievement, } \\
\text { concept } \\
\text { learning and } \\
\text { attitudes } \\
\text { towards } \\
\text { Science and } \\
\text { Technology } \\
\text { course in favor } \\
\text { of } \\
\text { experimental } \\
\text { group while } \\
\text { there isn't any } \\
\text { meaningful } \\
\text { difference } \\
\text { between their } \\
\text { metacognition }\end{array}$ & $\begin{array}{l}\text { The application } \\
\text { contributed } \\
\text { positively to the } \\
\text { development of } \\
\text { scientific process } \\
\text { skills, concept } \\
\text { implementation, } \\
\text { attitude and } \\
\text { creativity of } \\
\text { students. }\end{array}$ & $\begin{array}{l}\text { The conceptual } \\
\text { change approach } \\
\text { has been found to } \\
\text { improve the } \\
\text { achievement of } \\
\text { students, attitudes } \\
\text { and motivations } \\
\text { towards lessons, } \\
\text { and reduce } \\
\text { conceptual } \\
\text { misconceptions. }\end{array}$ & $\begin{array}{l}\text { It has been } \\
\text { found that } \\
\text { the } \\
\text { application } \\
\text { significantly } \\
\text { enhances the } \\
\text { successes, } \\
\text { problem } \\
\text { solving skills } \\
\text { and retention } \\
\text { of knowledge. }\end{array}$ & $\begin{array}{l}\text { While the creative } \\
\text { thinking skills of } \\
\text { students were } \\
\text { significantly affected, } \\
\text { attitudes towards } \\
\text { science and } \\
\text { technology lessons } \\
\text { and questioning skills } \\
\text { were not significantly } \\
\text { affected. }\end{array}$ & $\begin{array}{l}\text { The application has had a } \\
\text { significant impact on the } \\
\text { academic achievement of } \\
\text { students and their attitudes } \\
\text { toward science and technology. }\end{array}$ \\
\hline
\end{tabular}


Saltan, Türkyılmaz, Karaçaltı \& Kemal Bilir - Çukurova Üniversitesi Eğitim Fakültesi Dergisi, 47(1), 2018, 308-336

\begin{tabular}{|c|c|c|c|c|c|c|c|}
\hline & & awareness. & & & & & \\
\hline Author & Özer, M. (2012) & $\begin{array}{l}\text { Orunlu, E. E. } \\
(2012)\end{array}$ & Çelik, K. (2014) & Erdemir, N. (2012) & Özahioğlu, B. (2012) & Tercan, i.(2012) & Fidan, K. E.(2012) \\
\hline Sample & $\begin{array}{l}\text { 6th grade / } 46 \\
\text { Student }\end{array}$ & $\begin{array}{l}\text { 7th grade / } 48 \\
\text { Student }\end{array}$ & 6 th grade / 48 Student & $\begin{array}{l}\text { 8th grade / } 36 \\
\text { Student }\end{array}$ & $\begin{array}{l}\text { 6th grade / } 77 \\
\text { Student }\end{array}$ & $\begin{array}{l}\text { 7th grade / } 65 \\
\text { Student }\end{array}$ & $\begin{array}{l}\text { 7th grade / } 68 \\
\text { Student }\end{array}$ \\
\hline $\begin{array}{l}\text { Educational } \\
\text { Technology }\end{array}$ & $\begin{array}{l}\text { Computer } \\
\text { Assisted } \\
\text { Education }\end{array}$ & $\begin{array}{l}\text { Cooperative } \\
\text { Learning } \\
\text { Method }\end{array}$ & $\begin{array}{l}\text { Research Based } \\
\text { Learning }\end{array}$ & Animation & $\begin{array}{l}\text { Project Based } \\
\text { Learning }\end{array}$ & Smart Board & $\begin{array}{l}\text { Computer Based } \\
\text { Mind Mapping }\end{array}$ \\
\hline $\begin{array}{l}\text { The } \\
\text { Dependent } \\
\text { Variable }\end{array}$ & $\begin{array}{l}\text { Academic } \\
\text { achievement }\end{array}$ & $\begin{array}{l}\text { Academic } \\
\text { achievement }\end{array}$ & $\begin{array}{l}\text { Academic achievement } \\
\text { Attitude towards } \\
\text { Science and Technology } \\
\text { Lesson } \\
\text { Scientific process skills }\end{array}$ & $\begin{array}{l}\text { Academic } \\
\text { achievement }\end{array}$ & $\begin{array}{l}\text { Academic } \\
\text { achievement } \\
\text { Attitude towards } \\
\text { Science and } \\
\text { Technology Lesson } \\
\text { Scientific process } \\
\text { skills }\end{array}$ & $\begin{array}{l}\text { Academic } \\
\text { achievement } \\
\text { Attitude } \\
\text { towards Science } \\
\text { and Technology } \\
\text { Lesson } \\
\text { Motivation } \\
\end{array}$ & $\begin{array}{l}\text { Academic } \\
\text { achievement } \\
\text { Attitude towards } \\
\text { Science and } \\
\text { Technology } \\
\text { Lesson } \\
\text { Permanence }\end{array}$ \\
\hline Results & $\begin{array}{l}\text { The } \\
\text { implementation } \\
\text { of computer- } \\
\text { assisted } \\
\text { instruction } \\
\text { significantly } \\
\text { increased the } \\
\text { achievement of } \\
\text { students. }\end{array}$ & $\begin{array}{l}\text { It can be said that } \\
\text { the cooperative } \\
\text { teaching method } \\
\text { has a positive } \\
\text { effect on the } \\
\text { academic } \\
\text { achievement of } \\
\text { the students. }\end{array}$ & $\begin{array}{l}\text { It is thought that the } \\
\text { usage of inquiry based } \\
\text { learning will increase } \\
\text { students' achievement } \\
\text { and will develop their } \\
\text { science process skills } \\
\text { and attitudes toward } \\
\text { science and technology. }\end{array}$ & $\begin{array}{l}\text { The application of } \\
\text { the computer aided } \\
\text { animation method } \\
\text { has increased the } \\
\text { achievement of the } \\
\text { students. }\end{array}$ & $\begin{array}{l}\text { It has come to the } \\
\text { conclusion that } \\
\text { project-based } \\
\text { learning has } \\
\text { contributed positively } \\
\text { to students' attitudes } \\
\text { towards scientific } \\
\text { process skills, } \\
\text { attitudes towards } \\
\text { science and } \\
\text { technology, and } \\
\text { academic } \\
\text { achievements. }\end{array}$ & $\begin{array}{l}\text { The smart } \\
\text { board had a } \\
\text { positive effect } \\
\text { on the students' } \\
\text { academic } \\
\text { achievement } \\
\text { and attitudes } \\
\text { towards the } \\
\text { lesson, but had } \\
\text { no significant } \\
\text { effect on their } \\
\text { motivation. }\end{array}$ & $\begin{array}{l}\text { The computer- } \\
\text { based mind } \\
\text { mapping activities } \\
\text { have positively } \\
\text { influenced the } \\
\text { academic } \\
\text { achievement of } \\
\text { students, their } \\
\text { persistence and } \\
\text { their motivation } \\
\text { towards the } \\
\text { lesson. }\end{array}$ \\
\hline Author & Çetin, E.(2012) & $\begin{array}{l}\text { Bastem, } \\
\text { E.(2012) }\end{array}$ & Ayverdi, L. (2012) & rhan, A. (2012) & irkan, A. (2012) & urksoy, E. (2012) & Ermiş, F. U.(2012) \\
\hline
\end{tabular}


Saltan, Türkyılmaz, Karaçaltı \& Kemal Bilir - Çukurova Üniversitesi Eğitim Fakültesi Dergisi, 47(1), 2018, 308-336

\begin{tabular}{|c|c|c|c|c|c|c|c|}
\hline Sample & $\begin{array}{l}\text { 7th grade / } 64 \\
\text { Student }\end{array}$ & $\begin{array}{l}\text { 6th grade / } 77 \\
\text { Student }\end{array}$ & $\begin{array}{l}\text { 8th grade / } 30 \\
\text { Student }\end{array}$ & $\begin{array}{l}\text { 6th grade / } 40 \\
\text { Student }\end{array}$ & 7th grade / 2 Students & $\begin{array}{l}\text { 5th grade / } 121 \\
\text { Student }\end{array}$ & $\begin{array}{l}\text { 6th grade / } 34 \\
\text { Student }\end{array}$ \\
\hline $\begin{array}{l}\text { Educational } \\
\text { Technology }\end{array}$ & Caricature & Mind Maps & $\begin{array}{l}\text { Implementation } \\
\text { of Scientific } \\
\text { Creative } \\
\text { Activity }\end{array}$ & $\begin{array}{l}\text { Alternative } \\
\text { Assessment } \\
\text { Activities }\end{array}$ & $\begin{array}{l}\text { Computer Assisted } \\
\text { Education, Laboratory } \\
\text { Studies }\end{array}$ & $\begin{array}{lr}\text { Teaching } & \text { Enriched } \\
\text { With } \quad \text { Active } \\
\text { Learning } \\
\text { Techniques }\end{array}$ & Smart Board \\
\hline $\begin{array}{l}\text { Dependent } \\
\text { Variable }\end{array}$ & $\begin{array}{l}\text { Academic } \\
\text { achievement } \\
\text { Attitude } \\
\text { towards the } \\
\text { environment }\end{array}$ & $\begin{array}{l}\text { Academic } \\
\text { achievement }\end{array}$ & $\begin{array}{l}\text { Academic } \\
\text { achievement } \\
\text { Scientific creativity }\end{array}$ & $\begin{array}{l}\text { Academic } \\
\text { achievement } \\
\text { Permanence }\end{array}$ & $\begin{array}{l}\text { Academic } \\
\text { achievement } \\
\text { Attitude towards } \\
\text { Science and } \\
\text { Technology Lesson }\end{array}$ & $\begin{array}{l}\text { Academic } \\
\text { achievement } \\
\text { Attitude toward } \\
\text { Electricity in our } \\
\text { Daily Life unit }\end{array}$ & $\begin{array}{l}\text { Academic } \\
\text { achievement } \\
\text { Motivation }\end{array}$ \\
\hline Results & $\begin{array}{l}\text { Using } \\
\text { caricature in } \\
\text { science and } \\
\text { technology } \\
\text { lessons, will } \\
\text { increase the } \\
\text { academic } \\
\text { achievement } \\
\text { and will } \\
\text { provide } \\
\text { contribution to } \\
\text { their attitudes. }\end{array}$ & $\begin{array}{l}\text { It has been seen } \\
\text { that the } \\
\text { achievements } \\
\text { of the students } \\
\text { are more } \\
\text { successful in } \\
\text { the courses } \\
\text { conducted by } \\
\text { the mind } \\
\text { mapping } \\
\text { method. }\end{array}$ & $\begin{array}{l}\text { Results of the study } \\
\text { have shown that } \\
\text { activities increased } \\
\text { scientific creativity } \\
\text { and academic } \\
\text { achievements of } \\
\text { students. }\end{array}$ & $\begin{array}{l}\text { Alternative } \\
\text { measurement and } \\
\text { evaluation } \\
\text { techniques have } \\
\text { significantly } \\
\text { increased the } \\
\begin{array}{l}\text { achievements of } \\
\text { students. }\end{array}\end{array}$ & $\begin{array}{l}\text { The achievement and } \\
\text { attitudes of students } \\
\text { in the experimental } \\
\text { group with computer- } \\
\text { assisted instruction } \\
\text { differed significantly } \\
\text { from those in the } \\
\text { control group with } \\
\text { laboratory-based } \\
\text { instruction. }\end{array}$ & $\begin{array}{l}\text { Enriched teaching } \\
\text { with active learning } \\
\text { techniques has } \\
\text { shown that } \\
\text { students have a } \\
\text { significant effect on } \\
\text { academic } \\
\text { achievement and } \\
\text { attitudes towards } \\
\text { the unit. }\end{array}$ & $\begin{array}{l}\text { While the use of } \\
\text { smartboards in } \\
\text { the lessons did } \\
\text { not have a } \\
\text { significant effect } \\
\text { on student } \\
\text { achievement, it } \\
\text { positively } \\
\text { influenced } \\
\text { students' } \\
\text { motivation } \\
\text { towards their } \\
\text { lessons. }\end{array}$ \\
\hline Author & $\begin{array}{l}\text { Aktaş, M. } \\
\text { (2013) }\end{array}$ & $\begin{array}{l}\text { Dirim Özyurt, A. } \\
\text { (2013) }\end{array}$ & Yıldırım, N. (2013) & Kaman, A. (2013) & $\begin{array}{l}\text { Kocabaş Yılmaz, } \\
\text { Ş. S. (2013) }\end{array}$ & Yazman, i. (2013) & ğru, E. (2013) \\
\hline Sample & $\begin{array}{l}\text { 7th grade / } 32 \\
\text { Student }\end{array}$ & $\begin{array}{l}\text { 7th grade / } 66 \\
\text { Student }\end{array}$ & $\begin{array}{l}\text { 5th grade / } 83 \\
\text { Student }\end{array}$ & $\begin{array}{l}7 \text { th grade / } 60 \\
\text { Student }\end{array}$ & $\begin{array}{l}\text { 5th grade / } 70 \\
\text { Student }\end{array}$ & $\begin{array}{l}\text { 7th grade / } 55 \\
\text { Student }\end{array}$ & 6th grade / 52 Student \\
\hline $\begin{array}{l}\text { Educational } \\
\text { Technology }\end{array}$ & $\begin{array}{l}\text { Web-Based } \\
\text { Distance } \\
\text { Education }\end{array}$ & $\begin{array}{l}\text { Cooperative } \\
\text { Learning }\end{array}$ & $\begin{array}{l}\text { MEB Vitamin } \\
\text { Software }\end{array}$ & $\begin{array}{l}\text { Video Films } \\
\text { Prepared By The } \\
\text { Students }\end{array}$ & $\begin{array}{ll}\text { Electronic } & \text { Coope } \\
\text { Journal Assisted } & \text { Learni } \\
\text { Research-Based } & \text { Techn } \\
\text { Learning } & \text { 5E Lea } \\
\text { Strategy } & \end{array}$ & $\begin{array}{l}\text { Cooperative } \\
\text { Learning/ Jigsaw } \\
\text { Technique } \\
\text { 5E Learning Model }\end{array}$ & Mindstorms NXT \\
\hline
\end{tabular}


Saltan, Türkyılmaz, Karaçaltı \& Kemal Bilir - Çukurova Üniversitesi Eğitim Fakültesi Dergisi, 47(1), 2018, 308-336

\begin{tabular}{|c|c|c|c|c|c|c|c|}
\hline $\begin{array}{l}\text { Dependent } \\
\text { Variable }\end{array}$ & $\begin{array}{l}\text { Academic } \\
\text { achievement } \\
\text { Attitude } \\
\text { towards Science } \\
\text { and Technology } \\
\text { Lesson } \\
\text { Attitude } \\
\text { towards } \\
\text { computer }\end{array}$ & $\begin{array}{l}\text { Academic } \\
\text { achievement }\end{array}$ & $\begin{array}{l}\text { Academic } \\
\text { achievement } \\
\text { Reflective thinking }\end{array}$ & $\begin{array}{l}\text { Academic } \\
\text { achievement }\end{array}$ & $\begin{array}{l}\text { Academic } \\
\text { achievement } \\
\text { Attitude } \\
\text { towards Science } \\
\text { and Technology } \\
\text { Lesson } \\
\text { Scientific } \\
\text { process skills }\end{array}$ & $\begin{array}{l}\text { Academic } \\
\text { achievement } \\
\text { Permanence }\end{array}$ & $\begin{array}{l}\text { Academic achievement } \\
\text { Scientific process skills } \\
\text { Attitude towards } \\
\text { Science and Technology } \\
\text { Lesson }\end{array}$ \\
\hline Results & $\begin{array}{l}\text { Web-based } \\
\text { distance } \\
\text { education did } \\
\text { not significantly } \\
\text { affect students' } \\
\text { attitudes } \\
\text { towards the } \\
\text { course, } \\
\text { although it } \\
\text { seemed to have } \\
\text { a significant } \\
\text { effect on } \\
\text { student } \\
\text { achievement } \\
\text { and attitudes } \\
\text { towards } \\
\text { computer. }\end{array}$ & $\begin{array}{l}\text { The cooperative } \\
\text { learning } \\
\text { method has } \\
\text { proven to } \\
\text { significantly } \\
\text { enhance the } \\
\text { success of } \\
\text { students. }\end{array}$ & $\begin{array}{l}\text { The MEB vitamin } \\
\text { software has been } \\
\text { found to enhance } \\
\text { students' academic } \\
\text { achievement and } \\
\text { reflective thinking } \\
\text { skills. }\end{array}$ & $\begin{array}{l}\text { It has been seen } \\
\text { that teaching } \\
\text { science and } \\
\text { technology lessons } \\
\text { made with video } \\
\text { films prepared by } \\
\text { students is effective } \\
\text { in increasing } \\
\text { student } \\
\text { achievement. }\end{array}$ & $\begin{array}{l}\text { The academic } \\
\text { achievement of } \\
\text { students has } \\
\text { been positively } \\
\text { impacted but } \\
\text { there is no } \\
\text { significant } \\
\text { difference in } \\
\text { attitudes and } \\
\text { scientific } \\
\text { process skills. }\end{array}$ & $\begin{array}{l}\text { As a result of the } \\
\text { activities, there was } \\
\text { no significant } \\
\text { difference between } \\
\text { the achievement } \\
\text { scores of the students } \\
\text { and the retention test } \\
\text { achievement scores. }\end{array}$ & $\begin{array}{l}\text { The students in the } \\
\text { experimental group } \\
\text { developed positive } \\
\text { attitudes toward the } \\
\text { science and technology } \\
\text { course, increased their } \\
\text { academic achievement, } \\
\text { and finally developed } \\
\text { their science process } \\
\text { skills. }\end{array}$ \\
\hline Author & $\begin{array}{l}\text { Demirci, G. } \\
\text { (2013) }\end{array}$ & $\begin{array}{l}\text { Güneş, M. N. } \\
\text { (2013) }\end{array}$ & Aktaş, S. (2015) & Demirci, E. (2016) & Çetin, Y.S. (2013) & Sayın, Ş. (2015) & Keleş, M. (2015) \\
\hline Sample & $\begin{array}{l}\text { 7th grade / } 30 \\
\text { student }\end{array}$ & $\begin{array}{l}\text { 7th grade / } 84 \\
\text { student }\end{array}$ & 7 th grade & 7 th grade & 6 th grade & 7 th grade & 7th grade \\
\hline $\begin{array}{l}\text { Educational } \\
\text { Technology }\end{array}$ & $\begin{array}{l}\text { Humour And } \\
\text { Caricature }\end{array}$ & $\begin{array}{l}\text { 3D Visual } \\
\text { Material }\end{array}$ & Smart Board & Student Diaries & $\begin{array}{l}\text { The Prediction- } \\
\text { Observation-Explain } \\
\text { (POE) Strategy } \\
\text { Enriched by } \\
\text { Animations }\end{array}$ & Concept Cartoons & $\begin{array}{l}\text { Problem Based } \\
\text { Learning }\end{array}$ \\
\hline
\end{tabular}


Saltan, Türkyılmaz, Karaçaltı \& Kemal Bilir - Çukurova Üniversitesi Eğitim Fakültesi Dergisi, 47(1), 2018, 308-336

\begin{tabular}{|c|c|c|c|c|c|c|c|c|}
\hline $\begin{array}{l}\text { The } \\
\text { Dependent } \\
\text { Variable }\end{array}$ & $\begin{array}{l}\text { Academic } \\
\text { achievement } \\
\text { Motivation }\end{array}$ & \multicolumn{2}{|c|}{$\begin{array}{l}\text { Academic } \\
\text { achievement } \\
\text { Attitude towards } \\
\text { Science and } \\
\text { Technology } \\
\text { Lesson } \\
\text { Concept learning } \\
\text { Permanence }\end{array}$} & $\begin{array}{l}\text { Academic } \\
\text { achievement } \\
\text { Permanence }\end{array}$ & $\begin{array}{l}\text { Academic } \\
\text { achievement } \\
\text { Metacognitive skills }\end{array}$ & $\begin{array}{l}\text { Academic } \\
\text { achievement }\end{array}$ & $\begin{array}{l}\text { Academic } \\
\text { achievement } \\
\text { İnquiry learning } \\
\text { Motivation }\end{array}$ & $\begin{array}{l}\text { Academic } \\
\text { achievement } \\
\text { Permanence }\end{array}$ \\
\hline Results & $\begin{array}{l}\text { In the science } \\
\text { and technology } \\
\text { lessons using } \\
\text { humor and } \\
\text { cartoon, it can } \\
\text { be said that the } \\
\text { students are } \\
\text { more successful } \\
\text { and motivated } \\
\text { than the } \\
\text { traditional } \\
\text { methods. }\end{array}$ & \multicolumn{2}{|c|}{$\begin{array}{l}\text { It is seen that 3D } \\
\text { visual materials, } \\
\text { academic } \\
\text { success, students' } \\
\text { attitude to the } \\
\text { lesson and } \\
\text { conceptual } \\
\text { permanence. }\end{array}$} & $\begin{array}{l}\text { The use of } \\
\text { smart boards in } \\
\text { lessons has } \\
\text { increased the } \\
\text { students } \\
\text { successes and } \\
\text { permanence of } \\
\text { knowledge. }\end{array}$ & $\begin{array}{l}\text { The use of student } \\
\text { journals has } \\
\text { increased the } \\
\text { success of students } \\
\text { but has not had a } \\
\text { meaningful effect } \\
\text { on their cognitive } \\
\text { skills. }\end{array}$ & $\begin{array}{ll}\text { Animation-supported } \\
\text { Prediction- } \\
\text { Observation-Explain } \\
\text { (POE) strategy has } \\
\text { led to an increase in } \\
\text { the success of the } \\
\text { students. }\end{array}$ & $\begin{array}{l}\text { While the use of } \\
\text { concept cartoons in } \\
\text { the lessons did not } \\
\text { lead to a significant } \\
\text { difference in the } \\
\text { success of the } \\
\text { learners, it also led to } \\
\text { an increase in } \\
\text { interrogative learning } \\
\text { skills and motivation. }\end{array}$ & $\begin{array}{l}\text { Problem based } \\
\text { learning has led to an } \\
\text { increase in the } \\
\text { success of learners, } \\
\text { but not to a } \\
\text { significant increase in } \\
\text { the permanence of } \\
\text { knowledge. }\end{array}$ \\
\hline Author & \multicolumn{2}{|l|}{ Türkhan, S. (2013) } & \multicolumn{2}{|c|}{ Erdağı, S. (2014) } & Yenice, E. (2014) & Kistak, Ö. (2014) & \multicolumn{2}{|l|}{ Kilit, Ü. (2013) } \\
\hline Sample & \multicolumn{2}{|l|}{8 th grade } & \multicolumn{2}{|l|}{ 7th grade } & 8 th grade & 8 th grade & \multicolumn{2}{|l|}{7 th grade } \\
\hline $\begin{array}{l}\text { Educational } \\
\text { Technology }\end{array}$ & \multicolumn{2}{|l|}{ Concept Maps } & \multicolumn{2}{|c|}{ Station Technique } & 7E Learning Model & Context-based learning & \multicolumn{2}{|c|}{ Computer-Assisted Laboratory Method } \\
\hline $\begin{array}{l}\text { The } \\
\text { Dependent } \\
\text { Variable }\end{array}$ & \multicolumn{2}{|c|}{ Academic achievement } & \multicolumn{2}{|c|}{ Academic achievement } & Academic achievement & Misconception & \multicolumn{2}{|c|}{$\begin{array}{l}\text { Academic achievement } \\
\text { Attitude towards Science and Technology } \\
\text { Lesson }\end{array}$} \\
\hline Results & \multicolumn{2}{|c|}{$\begin{array}{l}\text { The use of concept maps } \\
\text { in science and } \\
\text { technology lessons has } \\
\text { increased the success of } \\
\text { students. }\end{array}$} & \multicolumn{2}{|c|}{$\begin{array}{l}\text { The application of } \\
\text { station technic in } \\
\text { science and technology } \\
\text { lessons has led to an } \\
\text { increase in the success } \\
\text { of students. }\end{array}$} & $\begin{array}{l}\text { The application of the 7E } \\
\text { learning model in } \\
\text { science and technology } \\
\text { lessons has led to an } \\
\text { increase in the success } \\
\text { of students. }\end{array}$ & $\begin{array}{l}\text { The application of a life- } \\
\text { based approach to } \\
\text { science and technology } \\
\text { lessons has led to } \\
\text { increased student } \\
\text { attitudes towards the } \\
\text { lesson. }\end{array}$ & \multicolumn{2}{|c|}{$\begin{array}{l}\text { The application of the computer-assisted } \\
\text { laboratory method in science and } \\
\text { technology course has resulted in an } \\
\text { increase in students' achievements and } \\
\text { attitudes towards the course. }\end{array}$} \\
\hline
\end{tabular}




\section{Result}

Findings about Application of Educational Technologies influences on academic achievement in Science and Technology Education

To find out investigate effect of educational technology on academic achievement it was examined 43(91\%) thesis. Results showed that 41 thesis indicated that using educational technologies made statistically significant differences in academic achievement of individuals. In other 2 thesis it does not find significant differences. The effect of educational technologies on academic achievement was summarized in Table 3.

Table 3.

The effect of educational technologies on academic achievement

\begin{tabular}{ll}
\hline $\begin{array}{l}\text { Statistically significant } \\
\text { differences }\end{array}$ & $1,3,4,5,6,7,8,9,11,12,14,15,16,17,18,19,20,21,22,23,24,25,26$, \\
$\begin{array}{l}\text { Not significant } \\
\text { Difference }\end{array}$ & $27,29,30,31,32,33,35,36,37,38,39,40,41,42,43,44,45,47$ \\
\hline
\end{tabular}

\section{Findings about Effect of Educational Technologies on the Attitude towards Science and Technology} Education

In $18(38 \%)$ of the thesis examined, the effect of the education technologies, used in science and technology course, on attitude toward this course was examined. There was a significant difference in the attitudes of the students towards science and technology lessons in 15 out of 17 thesis. In the three dissertations, there was no statistically significant difference in the attitudes of the students.

Table 4.

Effect of educational technologies on the attitude towards Science and Technology

$\begin{array}{ll}\begin{array}{l}\text { Statistically significant } \\ \text { differences }\end{array} & 3,4,7,8,9,11,14,17,19,20,21,26,29,35,37,47 \\ \text { Not significant Difference } & 1,13,33\end{array}$

Findings about Effect of Educational Technologies on Knowledge Persistence of Science and Technology Education

The effect of the education technologies on the persistence of information learned in science and technology lessons was examined in $9(20 \%)$ of the thesis examined. According to findings, 7 of the thesis showed a significant difference in the permanence of learned information. In the other 2 thesis, there was no significant difference in the permanence of the information summarized in Table 5.

Table 5.

The Effect of education technologies on knowledge persistence of science and technology course

Statistically

significant $\quad 5,6,8,20,24,36,37$

differences

Not significant

Difference

33,41 


\section{Findings about Effect of Educational Technologies on the scientific process success in Science and Technology Education}

In $9(19 \%)$ of the thesis examined the effect of educational technologies on scientific process skills was found. According to findings, there was a meaningful difference in the scientific process skills of the students in 7 of the thesis but there was no meaningful difference in the remaining 2 thesis.

Table 6.

Effect of Educational Technologies on the scientific process success in Science and Technology Education

Statistically significant differences $3,5,7,8,10,19,35$

Not significant Difference

17,33

\section{Research Designs Used in the Thesis}

In order to determine the effectiveness of educational technologies, quasi-experimental method was used in 41 (89\%) the thesis. The mixed method, both the qualitative and the quantitative method together, was used in 5 of them. The quasi-experimental method was applied as qualitative method and the descriptive method was applied for quantitative method in 3 thesis using mixed method. The remaining 2 thesis were utilized case study as the quantitative method. The research designs used in the thesis are shown in Table 7.

Table 7.

Research Designs of the Thesis

\begin{tabular}{ll}
\hline Design & Thesis \\
\hline & $1,3,4,5,6,8,9,10,11,12,13,14,15,16,17,20$, \\
Quasi-experimental & $21,22,23,25,27,28,29,30,31,32,33,34,35,36$, \\
& $37,38,39,40,41,42,43,44,45,46$ \\
Mixed (Quasi-experimental \& Descriptive method) & $2,18,19$ \\
Mixed (Quasi-experimental \&Case-Study) & 7,24 \\
\hline
\end{tabular}

\section{Data collection tools used in thesis examined}

In the thesis examined, the data collection tools used to determine the effect of the use of educational technologies in science technology courses on various variables (attitude / academic achievement, etc.) These tools can be gathered under the headings of test, questioner and open-ended questions. In many studies more than one data collection tools are used. Data collection tools are shown in Table 8.

Table 8.

Data Collection Tools

\begin{tabular}{ll}
\hline Tool & Thesis \\
\hline & $1,2,3,4,5,6,7,8,9,10,11,13,14,15,16,17$, \\
Test (Achivement \& Retention) & $18,19,20,22,23,24,25,26,27,28,29,30,31,32$, \\
& $33,34,36,37,38,40,41,42,43,44,45,46$. \\
Questioner (Attitude / Motivation etc.) & $1,3,4,7,8,10,11,12,13,16,18,19,20,21,25,27$, \\
Open-ended questions & $28,32,334$ \\
& $2,5,6,7,15,19,20,22,23,24,31,32,34,40,43,45$ \\
\hline
\end{tabular}

\section{Discussion \& Conclusion}

The purpose of the study is to identify the educational technologies used in elementary science and technology courses, and to determine their advantages and limitations. Based on this aim, the master's 
thesis and doctoral dissertations regarding the use of educational technology in science and technology courses and conducted in the last five years (2012-2016) were investigated.

The researcher of the thesis mostly preferred quasi experimental method (89\%) and some of them utilized mixed method. Test, questioner and open-ended questions were used for data collection. In many studies more than one data collection tools were applied. Especially in the last decade, it was spoken about the transition from a quantitative paradigm to a qualitative paradigm in the field of educational studies. However, the result of this study does not confirm this. As it can be seen, the semi-experimental method was used in nine without every ten studies. Besides this, motivation and attitude studies keep up to date.

The results of the study showed that statistically significant difference was reported in most of the thesis and dissertations (91\%) listed for academic achievement. In addition, it was revealed that statistically significant differences were reported in more than half of the thesis and dissertations (78\%) listed for the attitude toward science and technology course. Thus, it can be concluded that the use of educational technology in science and technology courses positively affect students' academic achievement and attitude in this course. As the reason of these results, it can be stated that educational technology usage in science and technology courses, in which abstract concepts and complex topics are covered, enrich instructional environment and provide persistence by addressing multiple sensory organs (Kahyaoğlu,2011). In a literature review conducted by Bacanak, Değirmenci, Karamustafaoğlu, and Karamustafaoğlu (2011), the method used in science education studies were examined and it was underlined that experimental method is the mostly used one. Another category in which significant difference was found is the effect of technology on knowledge persistence. In more than half of the reviewed studies (77\%), the use of educational technology in science and technology courses provided persistence. These finding indicate that use of educational technology in science and technology courses provides persistence and supports academic achievement. These results highlight the importance of the use of educational technology such as audio, video, animation, and simulation. It was clearly observed that these Technologies are more effective for persistence and academic achievement compared with the traditional methods.

In most of the thesis and dissertations (77\%) included in the study, significant differences were observed in terms of scientific process skills. According to this finding, conducting science and technology courses based on the scientific process skills (experimenting, interpreting data, hypothesizing etc.) is more successful than the traditional methods. The similar findings were found in the studies related with the scientific process (Geban,1990; Arslan,1995; Ercan,1996; Doğruöz,1998; Temiz, 2001). On the other hand, the study conducted by Ercan (1996) revealed that such factors as allocated time for science and technology course, crowded classrooms, intensive course content, lack of laboratory or lack of equipment negatively affect the development of the scientific process skills.

From all these results we can say that presented study explored that the current literature shows us the use of educational technology has a significant effect on science education. It can be deduced from these results that it would be beneficial to increase technology support at all levels where science education is carried out.

Especially when the "STEM" approach is considered, the use of technology besides science, mathematics and engineering will become even more important in primary and secondary education in the coming years. In our country, which is the greatest dynamism of well-trained human power, it will be a very important benefit to make science education peaceful and co-operating with science. On the other hand, using this connective approach in Educational Faculties teaching pre-service science teachers will lead them to utilize with similar activities when they start teaching in primary and secondary schools. Overall the result of the study can motivate both teacher and teacher educators to use educational technology in science classes. 


\section{Türkçe Sürümü}

\section{Giriş}

Gelişmiş toplumlarda eğitimin başarıya ulaşabilmesi için öğretmenlerin güncel bilgi ve teknolojiyi kullanması önem taşımaktadır. Bu nedenle eğitimin başarıya ulaşmasında öğretmenlerin nitelikleri ve yeterlilikleri büyük önem taşımaktadır (Bal ve Karademir, 2013). Bir öğretmenin yeterliliğinin ölçülebilmesi de ilk olarak pedagog Shulman tarafından incelenmiştir. Shulman'a (1986) göre bir öğretmenin pedagojik alan bilgisinin( $P A B)$ incelenmesi mesleğindeki uzmanlık bilgisini öğrenmede en etkili kavram olduğunu söyler. Bu bağlamda pedagojik alan bilgisinin bir öğretmenin alan bilgisi(AB) ve pedagojik bilgisinin(PB) birlikte kullanımı sonucu ortaya çıkacağını vurgulamıştır. 1980' li yıllardan sonra teknolojik gelişmelerin artması ve hayatımıza giren teknolojik cihazların kullanımı eğitim ortamında da teknoloji kullanımını artırmıştır. Mishra ve Koehler (2009) teknolojinin öğretmen yeterliliğine etkisini vurgulayarak teknolojik pedagojik alan bilgisini(TPAB) ortaya atmıştır. Ortaya atılan bu model etkili öğretim için alan bilgisi(AB), pedagoji bilgisi (PB)'ne teknoloji bilgisi(TB) de eklenerek teknolojik pedagojik alan bilgisi(TPAB) oluşturmaktadır. TPAB modeline göre öğretmenlerin sadece teknolojik bilgiye sahip olmaları yeterli değildir. Bunun yanı sıra etkili öğretimin sağlanabilmesi için öğretim sürecinde içeriği, pedagojiyi ve teknolojiyi birbirinden ayırmadan bir bütün olarak uygulanmalıdır.

Teknoloji, eğitimde fen ve matematik temel olmak üzere birçok alan derslerinde öğretimi desteklemek amacıyla kullanılmaktadır. Fen bilgisi dersinin teknoloji kullanımı konusunda ayrıcalıklı bir konuma sahiptir (Taşçı, Yaman ve Soran, 2010). Millî Eğitim Bakanlığının 2004-2005 Eğitim-Öğretim yılında yaptığı değişiklikle fen bilgisi dersi "Fen ve Teknoloji Dersi" olarak değiştirilmiş ve fen bilgisi dersi ile eğitim teknolojileri bütünleşmiştir. Fen dersi içeriği bakımından incelendiğinde soyut kavramların yer aldığı, karmaşık konuların bulunduğu dinamik bir yapıya sahip olduğu görülmektedir(Kahyaoğlu,2011). Bu sebeple yenilenen fen ve teknoloji dersiyle içeriğe dönük teknolojik beklentiler de artmıştır. Derslerin çeşitli materyaller (ses, video, animasyon, simülasyon) kullanılarak anlatılması öğretim ortamlarının zenginliğini artırarak öğrencilerin birden fazla duyu organını kullanmasına olanak sağlamaktadır (Kahyaoğlu,2011). Diğer yandan ders kitaplarıyla paralel hazırlanan güncel kaynaklar; uygulama cd'leri, elektronik dokümasyonlar, dijital çalışma yaprakları ve bilgi alışverişinin gerçekleştiği çevrimiçi görüşmeler sunan internet platformları gibi birçok öğrenme ortamı sunmaktadır (Taşçı, Yaman ve Soran, 2010). Bu öğrenme ortamları da öğrencilerin derse olan ilgisini olumlu yönde etkileyerek dersi daha anlaşılır kılmaktadır. Alan yazın incelendiğinde fen dersine eğitim teknolojilerinin entegrasyonu ile istenen hedef davranışlara daha kolay ulaşıldığı, öğrencilerin fen dersine karşı sahip olması gereken becerilerinin geliştiği ve içeriğin aktarılmasında zamandan kazanç sağladığı belirtilmiştir (Jimoyiannis \& Komis, 2001). Bir başka ifadeyle eğitim teknolojilerinin fen ve teknoloji derslerinde kullanarak kavramların ve içeriğin sunumunda karşılaşılacak zorlukları aşmak, içeriğe uygun zihinsel teknikleri ve bilginin kolayca yapılandırılmasını sağlamaktır. Yenilenen Fen ve Teknoloji dersi müfredatı öğrenci merkezli olan yapılandırmacı yaklaşımı benimsemektedir. Öğrenci merkezli sınıflarda öğretmenin rolü, bilgiyi aktaran değil ipuçları vererek öğrencilerin bilgiyi bulmalarına ve zihinlerinde yapılandırmalarına rehberlik edendir. Bu yaklaşım öğrencilerin yaparak yaşayarak öğrenmelerine fırsat sunmaktadır(Erdoğan,2007). Bu müfredatla yeni dersin getirdiği olumlu yönlerinden biride öğrencilerin bilgiyi daha kolay yapılandırması ve ezber bilgiden uzaklaşmasıdır. Geleneksel sınıf ortamlarını yanı sıra fen ve teknoloji derslerinin laboratuvar ortamında verilmesi öğrencinin motivasyonunu artırıcı etki oluşturmaktadır. Bunun yanı sıra öğrenim gören öğrenciler "okulda ve okul dışında elde ettiği bilgiyi gerçek yaşam ile ilişkilendirebildiği için bilginin kalıcılığı sağlanmaktadır."( Erdoğan,2007).

Fen ve teknoloji derslerine belirtilen avantajları sunabilme, eğitim teknolojilerini derslerine olumlu yönde yansıtabilmelerinde öğretmenler anahtar role sahiptir(Kahyaoğlu,2011). Fen ve teknolojileri dersleri öğrencilerin zorlandığı dersler arasında yer almaktadır. Bu zorluğu aşmak, derslerin geleneksel yöntemden daha çok çağdaş yöntemlere göre yürütülmesi nitelikli öğretmenlerle mümkün olacaktır. Bu sayede derslerin daha zevkli geçmesi beklenmektedir. Öğretmenlerin öğrenme ortamlarını zenginleştirmek için yeni teknolojileri kullanma konusunda ki bilgi, beceri ve yeteneğe sahip olmaları da önemlidir. Bu bağlamda fen 
eğitiminde kullanılan teknolojilerin incelenmesi, avantajlarının ve sınılılıklarının belirlenmesi oldukça önem taşımaktadır. Bu çalışma sayesinde bir taraftan fen eğitiminde kullanılan güncel eğitim teknolojilerinin uygulamalarda ki avantajları ve sınırlııkları gözler önüne serilecek diğer taraftan disiplinler arası bir bakışla ülkemizde ki mevcut durum bilim insanların ve uygulamada görev yapan öğretmenlerimizin dikkatine sunulacaktır. Her ne kadar Fen eğitimde tarama çalışmaları yer alsa da bahsi geçen konular öğretim teknolojileri açısından yeniden ele alınmaya intiyaç duymaktadır. Örneğin Karamustafaoğlu (2015) tarafından yürütülen alanyazın taramasında Fen ve teknoloji eğitimde temel yönelimler incelenmiş ve sekiz başlık altında toplanmıştır bunlar; Disiplinler Arası Ilişki, Eğitim Felsefesi, Fen ve Teknolojiye Yönelik Tutum, Öğretmen Yetiştirme, Bilgisayar Destekli Fen ve Teknoloji Öğretimi, Program Geliştirme, Öğrenme Etkinlikleri ve Ölçme-Değerlendirme. Göründüğü üzere bilgisayar destekli fen ve teknoloji eğitimi ayrı bir başlık olarak ortaya çıkmışır. Ülkemizde yürütülen ve alan yazında yer alan makale çalışmalarının yanı sıra yüksek lisans ve doktora çalışmaları ışığında fen eğitiminde teknoloji kullanımının incelenmesi önem arz etmektedir.

\section{Çalışmanın Amacı}

Çalışmanın amacı ortaokul fen ve teknoloji derslerinde kullanılan eğitim teknolojilerinin neler olduğunu belirlemek, avantajlarını ve sınılıııklarını tespit etmektir. Bu bağlamda son beş yılda (2012-2016) yayımlanmış eğitim teknolojilerinin fen ve teknoloji derslerinde kullanılması ile ilgili doktora ve yüksek lisans tezleri incelenmiştir.

\section{Yöntem}

Bu çalışmada Türkiye'de eğitim veren okullarda Fen ve Teknoloji derslerinde Eğitim Teknolojilerinin kullanıldığı Yüksek lisans ve Doktora Tezleri incelenmiştir. Bu inceleme, Kapsamın Belirlenmiş Tarama Çalışması yöntemi kullanılarak yapıımışır. Bu yöntemin kullanımı için izlenilecek yol Arksey ve O' Malley (2005)'in ortaya koyduğu çerçeve dâhilin de yürütülmüştür. Bu çerçevenin aşamaları şu şekildedir; (1) Araştırma sorularını belirlenmesi, (2) ilgili çalışmaların belirlenmesi, (3) Çalışmaların seçimi, (4) Verilerin grafik haline getirilmesi, (5) Sonuçların harmanlanması, özetlenmesi ve raporlanmasıdır. Yürütülen çalışma kapsamında sırasıyla bu adımlar takip edilmiştir.

\section{Araştırma Sorularının Belirlenmesi}

Çalışma ortaokul Fen ve Teknoloji Derslerinde eğitim teknolojilerinin kullanımı üzerine yapılan yüksek lisans ve doktora tezlerinin incelenmesi amacıyla yapılmıştır. Bu çalışma kapsamında konu ile ilgili sorular şu şekildedir:

1. Eğitim Teknolojilerinin uygulanması Fen ve Teknoloji dersindeki akademik başarıyı etkilemekte midir? Etkilediyse ne yönde etkilemektedir?

2. Eğitim Teknolojilerinin uygulanması Fen ve Teknoloji dersine karşı tutumu etkilemekte midir? Etkilediyse ne yönde etkilemektedir?

3. Eğitim Teknolojilerinin uygulanması Fen ve Teknoloji dersine ait bilgi kalıcılı̆ıını etkilemekte midir? Etkilediyse ne yönde etkilemektedir?

4. Eğitim Teknolojilerinin uygulanması Fen ve Teknoloji dersindeki bilimsel süreç başarılarını etkilemekte midir? Etkilediyse ne yönde etkilemektedir?

5. Incelenen tezlerde hangi araştırma desenleri uygulanmıştır?

6. Incelenen tezlerde hangi veri toplama araçları kullanılmışıı?

\section{ilgili Çalışmaları Belirleme}

Türkiye' de ortaöğretim Fen ve Teknoloji dersinde eğitim teknolojilerinin kullanımını ile ilgili tarama yapabilmek için "Fen ve Teknoloji Dersi" arama terimi seçilmiştir. Bu terim seçilerek fen ve teknoloji dersinde eğitim teknolojilerinin kullanımına yönelik farklı örnekler bulunması amaçlanmıştır. "Fen ve Teknoloji Dersi" arama terimi belirlendikten sonra çalışma için kullanılacak yüksek lisans ve doktora tezlerinin belirlenmesi için hariç tutma ve kapsama kriterleri oluşturulmuştur. Bu kriterler "Fen ve Teknoloji Dersi" arama terimi kullanılarak bulunan ve örnek teşkil eden tezler incelenerek oluşturulmuştur. Hariç tutma ve kapsama kriterleri Tablo1' de gösterilmiştir. Eğitim teknolojilerinin fen ve teknoloji dersindeki güncel kullanımını belirleyebilmek amacıyla son 5 yıl (2012-2016) kabul edilmiştir. Hariç tutma ve kapsama 
kriterlerine göre Yök Ulusal Tez Merkezi'nde arama yapılmıştır. Yükseköğretim Kurulu Yayın ve Dokümantasyon Daire Başkanlığı kapsamında hizmet veren Ulusal Tez Merkezinde arama yapılmasının amacı Türkiye' de eğitim veren üniversitelerde yapılan yüksek lisans ve doktora tezlerini kapsamasıdır.

Tablo1.

Kapsama ve hariç tutma kriterleri

\begin{tabular}{|c|c|c|}
\hline Ölçüt & Kapsama & Hariç tutma \\
\hline $\begin{array}{c}\text { Zaman } \\
\text { Çalışma Odağı }\end{array}$ & $\begin{array}{l}\text { Son } 5 \text { yıl (2012-2016) } \\
\text { Örgün eğitim içeriği (ortaokul) }\end{array}$ & $\begin{array}{l}\text { Bu tarih ve zaman dışı çalışmalar } \\
\text { informal öğrenme içerikleri ile } \\
\text { yürütülen çalışmalar }\end{array}$ \\
\hline Literatür Odağı & $\begin{array}{l}\text { Örgün eğitim içeriği ile ilgili faaliyetler } \\
\text { ve ilgili sonuçlar (örneğin akademik } \\
\text { başarı, öğrenmede kalıcılık, bilimsel } \\
\text { süreç becerileri, tutum). } \\
\text { 2008-2016 yılları arasında yapılmış } \\
\text { yüksek lisans ve doktora tezleri }\end{array}$ & $\begin{array}{l}\text { Fen ve teknoloji dersi haricinde } \\
\text { kullanılan eğitim teknolojileri, } \\
\text { alakasız fen ve teknoloji dersi } \\
\text { tezleri ve } 2008-2011 \text { yılları } \\
\text { arasında yapılmış yüksek lisans ve } \\
\text { doktora tezleri }\end{array}$ \\
\hline Örnek & $\begin{array}{l}\text { İlköğretim 6. sınıf fen ve teknoloji } \\
\text { dersi "maddenin tanecikli yapısı" } \\
\text { ünitesinin öğretiminde, bilgisayar } \\
\text { destekli ve bilgisayar temelli öğretim } \\
\text { yöntemlerinin, akademik başarıya ve } \\
\text { kalıcılığa etkisi }\end{array}$ & $\begin{array}{l}\text { İlköğretim 7. sınıflarda 'simetri' } \\
\text { konusunun öğretiminde eğitim } \\
\text { teknolojilerinin başarı ve tutuma } \\
\text { etkisi }\end{array}$ \\
\hline
\end{tabular}

\section{Çalışma Seçimi}

Belirlenen "Fen ve Teknoloji Dersi"arama terimi kullanılarak Ulusal Tez Merkezinde 06.12.2016 tarihinde yapılan arama sonucu 49 doktora, 344 yüksek lisans tezine ulaşıımıştır. Başıkların ve özetlerin incelenmesi sonucu hariç tutma ve kapsama kriterlerine göre tezler incelenmiştir. Tez seçim sürecinde PRISMA (2009) modeli kullanıımıştır (Moher, Liberate, Tetzlaff, Altman, \&PRISMA Group, 2009). Tez seçim süreci Şekil 2'de gösterilmiştir.
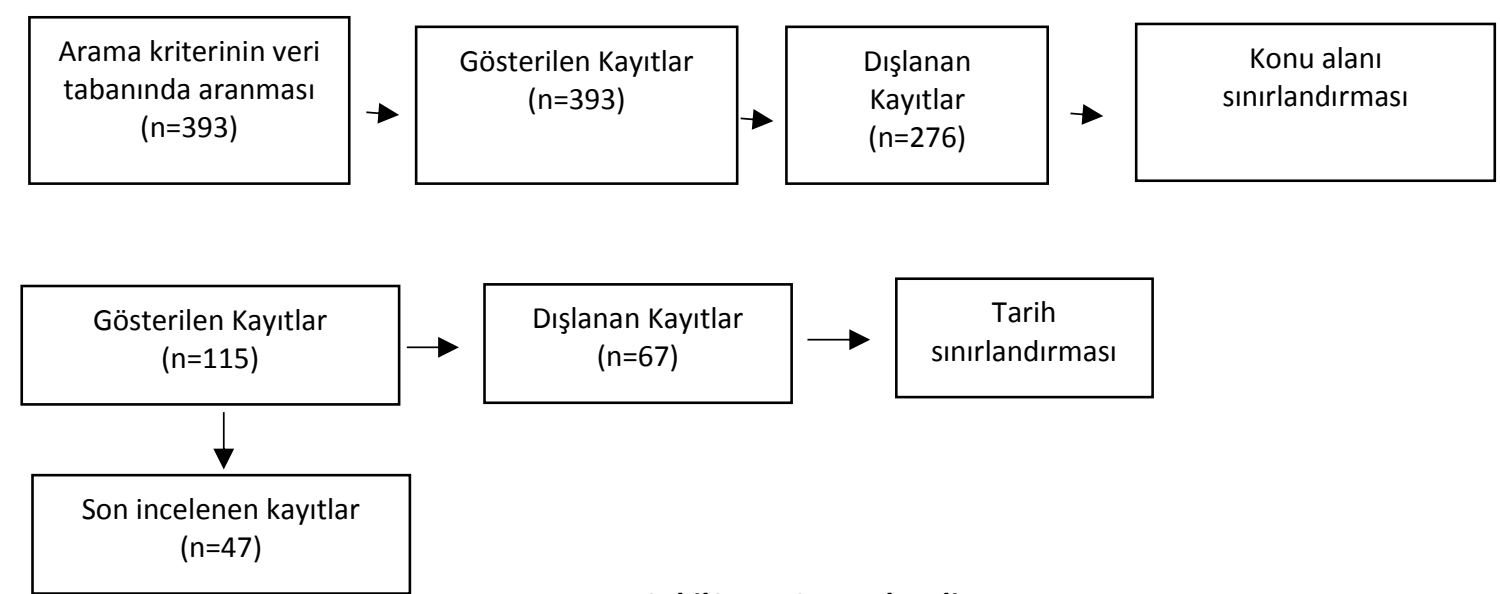

Şekil2: PRISMA akış diyagramı 
Tablo2.

incelenen tez çalışmalarııın bulguları

\begin{tabular}{|c|c|c|c|c|c|c|c|}
\hline Yazar & $\begin{array}{l}\text { Özdemir, A. M. } \\
\text { (2012) }\end{array}$ & Sever, D. (2012) & Güçlüer, E. (2012) & Çeliker, H. D. (2012) & Daşdemir, i. (2012) & Gürbüz, F. (2012) & Öztürk, N. (2013) \\
\hline Örnek & 5. Sınıf / 25 Öğrenci & $\begin{array}{l}\text { 7. Sınıf / } 25 \\
\text { Öğrenci }\end{array}$ & $\begin{array}{l}\text { 7. Sınıf / } 35 \\
\text { Öğrenci }\end{array}$ & 7. Sinıf & 8. Sınıf / 37 Öğrenci & 6. Sınıf / 45 Öğrenci & 6. Sınıf / 43 Öğrenci \\
\hline $\begin{array}{l}\text { Eğitim } \\
\text { Teknolojisi }\end{array}$ & $\begin{array}{l}\text { Kavramsal Değişim } \\
\text { Yaklaşımı ve Kavram } \\
\text { Haritaları }\end{array}$ & $\begin{array}{l}\text { Araştırma Temelli } \\
\text { Öğrenme Yak. }\end{array}$ & $\begin{array}{l}\text { Fen } \\
\text { Okuryazarlığını } \\
\text { Geliştirici } \\
\text { Etkinlikler }\end{array}$ & Proje Tabanlı Öğrenme & Animasyon & $\begin{array}{l}7 \text { E Öğrenme } \\
\text { Modeli }\end{array}$ & $5 \mathrm{E}$ Öğrenme Modeli \\
\hline $\begin{array}{l}\text { Bağımlı } \\
\text { Değişkenler }\end{array}$ & $\begin{array}{l}\text { Başarı } \\
\text { Tutum } \\
\text { Motivasyon }\end{array}$ & Derse karşı direnç & $\begin{array}{l}\text { Başarı } \\
\text { Tutum } \\
\text { Bilimsel süreç } \\
\text { becerileri }\end{array}$ & $\begin{array}{l}\text { Başarı } \\
\text { Bilimsel yaratıcılık } \\
\text { becerileri } \\
\text { Tutum }\end{array}$ & $\begin{array}{l}\text { Başarı } \\
\text { Kalıcılık } \\
\text { Bilimsel süreç } \\
\text { becerileri }\end{array}$ & $\begin{array}{l}\text { Başarı } \\
\text { Kalıcılık }\end{array}$ & $\begin{array}{l}\text { Başarı } \\
\text { Motivasyon } \\
\text { Tutum } \\
\text { Bilimsel süreç } \\
\text { becerileri } \\
\text { Öz yeterlilik }\end{array}$ \\
\hline Sonuçlar & $\begin{array}{l}\text { Kavramsal değişim } \\
\text { ve kavram } \\
\text { haritalarının } \\
\text { öğrencilerin } \\
\text { başarılarında ve } \\
\text { derse karşı olumlu } \\
\text { tutum geliştirmelerin } \\
\text { de bir etkisi olmadığı } \\
\text { gözlenmiştir. } \\
\text { Fakat } \\
\text { motivasyonların da } \\
\text { anlamlı bir artışa } \\
\text { sebep olmuştur. }\end{array}$ & $\begin{array}{l}\text { Araştırma temelli } \\
\text { öğrenme } \\
\text { yaklaşımı ile } \\
\text { işlenen derslerde } \\
\text { öğrencilerin dersi } \\
\text { işlemekten } \\
\text { hoşlandıkları ve } \\
\text { derse karşı } \\
\text { oluşturmuş } \\
\text { oldukları } \\
\text { dirençlerini } \\
\text { azaltmalarına } \\
\text { sebep olmuştur. }\end{array}$ & $\begin{array}{l}\text { Fen okuryazarlığı } \\
\text { geliştirici } \\
\text { etkinlikler } \\
\text { öğrencilerin } \\
\text { başarılarının } \\
\text { artmasına, derse } \\
\text { yönelik } \\
\text { tutumlarının } \\
\text { artmasına ve } \\
\text { bilimsel süreç } \\
\text { becerilerinin } \\
\text { artmasına sebep } \\
\text { olmuştur. }\end{array}$ & $\begin{array}{l}\text { Proje tabanlı öğretimin } \\
\text { öğrencilerin akademik } \\
\text { başarılarının artmasına, } \\
\text { bilimsel yaratııılık } \\
\text { becerilerinin artmasına ve } \\
\text { derse yönelik tutumlarının } \\
\text { artmasına sebep olmuştur. }\end{array}$ & $\begin{array}{l}\text { Fen ve teknoloji } \\
\text { dersinde } \\
\text { animasyon ile } \\
\text { öğretim yapılması } \\
\text { öğrencilerin } \\
\text { akademik } \\
\text { başarılarının } \\
\text { artmasına, bilgilerin } \\
\text { kalıııı̆ıının } \\
\text { artmasına ve } \\
\text { bilimsel süreç } \\
\text { becerilerinin } \\
\text { artmasına sebep } \\
\text { olmuştur. }\end{array}$ & $\begin{array}{l}\text { Fen ve teknoloji } \\
\text { dersinin } 7 \mathrm{E} \\
\text { öğrenme modeline } \\
\text { göre işlenmesi } \\
\text { öğrencilerini } \\
\text { başarılarının } \\
\text { artmasına ve } \\
\text { bilgilerinin } \\
\text { kalıclığının } \\
\text { artmasına sebep } \\
\text { olmuştur. }\end{array}$ & $\begin{array}{l}7 \text { E öğrenme } \\
\text { modelinin } \\
\text { kullanılması } \\
\text { öğrencilerin } \\
\text { başarılarının, } \\
\text { motivasyonlarının } \\
\text { artmasına, } \\
\text { tutumlarının, bilimsel } \\
\text { süreç becerilerinin } \\
\text { artmasına ve öz } \\
\text { yeterliliklerinin } \\
\text { olumlu yönde } \\
\text { etkilenmesine sebep } \\
\text { olmuştur. }\end{array}$ \\
\hline Yazar & $\begin{array}{l}\text { Sünkür, M. Ö. } \\
\text { (2013) }\end{array}$ & Çakar, E. (2013) & $\begin{array}{l}\text { Demirçalı, S. } \\
\text { (2014) }\end{array}$ & Uyanık, G. (2014) & Aşiroğlu, S. (2014) & Parsa, M. K. (2016) & Kurt, Y. (2012) \\
\hline
\end{tabular}


Saltan, Türkyılmaz, Karaçaltı \& Kemal Bilir - Çukurova Üniversitesi Eğitim Fakültesi Dergisi, 47(1), 2018, 308-336

\begin{tabular}{|c|c|c|c|c|c|c|c|}
\hline Örnek & $\begin{array}{l}\text { 7. Sınıf / } 79 \\
\text { Öğrenci }\end{array}$ & $\begin{array}{l}\text { 7. Sınıf / } 59 \\
\text { Öğrenci }\end{array}$ & $\begin{array}{l}\text { 7. Sınıf / } 48 \\
\text { Öğrenci }\end{array}$ & 4. Sınıf / 50 Öğrenci & 5. Sınıf / 39 Öğrenci & 8. Sınıf / 49 Öğrenci & 6. Sınıf / 128 Öğrenci \\
\hline $\begin{array}{l}\text { Eğitim } \\
\text { Teknolojisi }\end{array}$ & $\begin{array}{l}\text { Tahmin Et-Gözle- } \\
\text { Açıkla Yöntemi ile } \\
\text { Desteklenmiş } \\
\text { Yansıtıcı } \\
\text { Düşünmeye } \\
\text { Dayalı Öğretim }\end{array}$ & $\begin{array}{l}\text { Araştırmaya } \\
\text { Dayalı Öğrenme }\end{array}$ & $\begin{array}{l}\text { Fen-Teknoloji- } \\
\text { Toplum (FTT) } \\
\text { Yaklaşımı }\end{array}$ & $\begin{array}{l}\text { Kavramsal Değişim } \\
\text { Yaklaşımı }\end{array}$ & $\begin{array}{l}\text { Aktif Öğrenme } \\
\text { Yaklaşımı }\end{array}$ & $\begin{array}{l}\text { İşbirlikli Sorgulama } \\
\text { Yaklaşımı }\end{array}$ & 5 E Öğrenme Modeli \\
\hline $\begin{array}{l}\text { Bağımlı } \\
\text { Değişkenler }\end{array}$ & $\begin{array}{l}\text { Başarı } \\
\text { Tutum } \\
\text { Kalıcılık } \\
\text { Bilimsel süreç } \\
\text { becerileri } \\
\text { Akademik risk } \\
\text { alma }\end{array}$ & $\begin{array}{l}\text { Başarı } \\
\text { Tutum } \\
\text { Kavram öğrenme } \\
\text { düzeyleri } \\
\text { Üstbiliş } \\
\text { farkındalık } \\
\text { düzeyleri }\end{array}$ & $\begin{array}{l}\text { Tutum } \\
\text { Yaratıcılık } \\
\text { Bilimsel süreç } \\
\text { becerileri } \\
\text { Kavram uygulama } \\
\text { becerileri }\end{array}$ & $\begin{array}{l}\text { Başarı } \\
\text { Tutum } \\
\text { Motivasyon } \\
\text { Kavram yanılgısı }\end{array}$ & $\begin{array}{l}\text { Başarı } \\
\text { Kalıcılık } \\
\text { Problem çözme } \\
\text { becerileri }\end{array}$ & $\begin{array}{l}\text { Tutum } \\
\text { Yaratıcı Düşünme } \\
\text { Sorgulama } \\
\text { becerileri }\end{array}$ & $\begin{array}{l}\text { Başarı } \\
\text { Tutum }\end{array}$ \\
\hline Sonuçlar & $\begin{array}{l}\text { Uygulanan } \\
\text { öğretim programı } \\
\text { öğrencilerin } \\
\text { başarılarının } \\
\text { artmasına, } \\
\text { tutumlarının } \\
\text { olumlu yönde } \\
\text { değişmesine, } \\
\text { bilgilerinin } \\
\text { kalıılığııın } \\
\text { artmasını, } \\
\text { bilimsel süreç } \\
\text { becerilerinin } \\
\text { artmasına, } \\
\text { akademik risk } \\
\text { alma } \\
\text { yeteneklerinin } \\
\text { artmasına sebep } \\
\text { olmuştur. }\end{array}$ & $\begin{array}{l}\text { Araştırmaya } \\
\text { dayalı öğretim } \\
\text { programının } \\
\text { uygulanması } \\
\text { öğrencilerin } \\
\text { başarılarının ve } \\
\text { kavram öğrenme } \\
\text { düzeylerinin } \\
\text { artmasına, } \\
\text { tutumlarının } \\
\text { olumlu yönde } \\
\text { etkilenmesine } \\
\text { sebep olmuştur. } \\
\text { Ancak üst biliş } \\
\text { farkındalık } \\
\text { düzeylerine } \\
\text { olumlu yönde bir } \\
\text { etkisi olmamıştır. }\end{array}$ & $\begin{array}{l}\text { Fen-Teknoloji- } \\
\text { Toplum (FTT) } \\
\text { Yaklaşımı ile } \\
\text { öğretim yapııması } \\
\text { öğrencilerin } \\
\text { tutumlarının } \\
\text { olumlu yönde } \\
\text { artmasına, } \\
\text { yaratııılık } \\
\text { düzeylerinin } \\
\text { artmasına ve } \\
\text { bilimsel süreç } \\
\text { becerilerinin } \\
\text { artmasına, } \\
\text { kavram uyulama } \\
\text { becerilerinin } \\
\text { artmasına sebep } \\
\text { olmuştur. }\end{array}$ & $\begin{array}{l}\text { Kavramsal değişim } \\
\text { yaklaşımının uygulanması } \\
\text { öğrencilerin başarılarının } \\
\text { artmasına } \\
\text { motivasyonlarının } \\
\text { artmasına ve kavramsal } \\
\text { yanılgılarının azalmasına } \\
\text { sebep olmuştur. Ancak } \\
\text { öğrencilerin tutumlarında } \\
\text { bir değişime sebep } \\
\text { olmamıştır. }\end{array}$ & $\begin{array}{l}\text { Aktif öğrenme } \\
\text { yaklaşımının } \\
\text { uygulanması } \\
\text { öğrencilerin } \\
\text { başarılarının } \\
\text { artmasına, problem } \\
\text { çözme becerilerinin } \\
\text { azalmasına sebep } \\
\text { olmuştur. Ancak } \\
\text { bilgilerin kalıcılığını } \\
\text { anlamlı bir şekilde } \\
\text { değişmesine sebep } \\
\text { olmamıştır. }\end{array}$ & $\begin{array}{l}\text { Fen ve teknoloji } \\
\text { dersinde işbirlikli } \\
\text { sorgulama } \\
\text { yaklaşımının } \\
\text { uygulanması } \\
\text { öğrencilerin yaratıcı } \\
\text { düşünme } \\
\text { becerilerinin } \\
\text { artmasına sebep } \\
\text { olmuştur. Tutum ve } \\
\text { sorgulama } \\
\text { becerilerinde } \\
\text { anlamlı bir değişliğe } \\
\text { sebep olmamıştır. }\end{array}$ & $\begin{array}{l}\text { Fen ve teknoloji } \\
\text { dersinde } 5 \mathrm{E} \text { öğrenme } \\
\text { modelinin } \\
\text { uygulanması } \\
\text { öğrencilerin } \\
\text { başarılarının } \\
\text { artmasına ve derse } \\
\text { karşı tutumlarının } \\
\text { olumlu yönde } \\
\text { değişmesine sebep } \\
\text { olmuştur. }\end{array}$ \\
\hline
\end{tabular}


Saltan, Türkyılmaz, Karaçaltı \& Kemal Bilir - Çukurova Üniversitesi Eğitim Fakültesi Dergisi, 47(1), 2018, 308-336

\begin{tabular}{|c|c|c|c|c|c|c|c|}
\hline Yazar & Özer, M. (2012) & Orunlu, E. E. (2012) & Çelik, K. (2014) & Erdemir, N. (2012) & Özahioğlu, B. (2012) & Tercan, i..(2012) & Fidan, K. E.(2012) \\
\hline Örnek & $\begin{array}{l}\text { 6. Sınıf / } 46 \\
\text { Öğrenci }\end{array}$ & 7. Sınıf / 48 Öğrenci & $\begin{array}{l}\text { 6. Sınıf / } 48 \\
\text { Öğrenci }\end{array}$ & 8. Sınıf / 36 Öğrenci & 6. Sınıf / 77 Öğrenci & 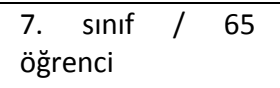 & 7. sınıf / 68 öğrenci \\
\hline $\begin{array}{l}\text { Bağımlı } \\
\text { Değişkenler }\end{array}$ & $\begin{array}{l}\text { Bilgisayar } \\
\text { Destekli Öğretim }\end{array}$ & $\begin{array}{l}\text { İşbirlikli Öğrenme } \\
\text { Yöntemi }\end{array}$ & $\begin{array}{l}\text { Araştırmaya } \\
\text { Dayalı Öğrenme } \\
\text { Yöntemi }\end{array}$ & $\begin{array}{l}\text { Bilgisayar Destekli } \\
\text { Animasyon Yöntemi }\end{array}$ & $\begin{array}{l}\text { Proje Tabanlı } \\
\text { Öğrenme }\end{array}$ & Akıllı Tahta & Zihin Destekli Harita \\
\hline $\begin{array}{l}\text { Pedagojik } \\
\text { Yaklaşımlar }\end{array}$ & Başarı & $\begin{array}{l}\text { Başarı } \\
\text { Tutum }\end{array}$ & $\begin{array}{l}\text { Başarı } \\
\text { Tutum } \\
\text { Bilimsel süreç } \\
\text { becerileri }\end{array}$ & Başarı & $\begin{array}{l}\text { Başarı } \\
\text { Tutum } \\
\text { Bilimsel süreç } \\
\text { becerileri }\end{array}$ & $\begin{array}{l}\text { Başarı } \\
\text { Tutum } \\
\text { Motivasyon }\end{array}$ & $\begin{array}{l}\text { Akademik Başarı } \\
\text { Tutum } \\
\text { Kalıcılık }\end{array}$ \\
\hline Sonuçlar & $\begin{array}{l}\text { Fen ve teknoloji } \\
\text { dersinde } \\
\text { bilgisayar } \\
\text { destekli } \\
\text { öğretimin } \\
\text { uygulanması } \\
\text { öğrencilerin } \\
\text { başarılarının } \\
\text { artmasına sebep } \\
\text { olmuştur. }\end{array}$ & $\begin{array}{l}\text { Fen ve teknoloji } \\
\text { dersinde işbirlikli } \\
\text { öğrenme yönteminin } \\
\text { uygulanması } \\
\text { öğrencilerin } \\
\text { başarılarının } \\
\text { artmasına ve } \\
\text { tutumlarının olumlu } \\
\text { yönde değişmesine } \\
\text { sebep olmuştur. }\end{array}$ & $\begin{array}{l}\text { Fen ve teknoloji } \\
\text { dersinde } \\
\text { araştırmaya dayalı } \\
\text { öğrenme } \\
\text { yönteminin } \\
\text { uygulanması } \\
\text { öğrencilerin } \\
\text { başarılarının } \\
\text { artmasına, } \\
\text { bilimsel süreç } \\
\text { becerilerinin daha } \\
\text { fazla gelişmesine } \\
\text { ve tutumlarının } \\
\text { olumlu yönde } \\
\text { gelişmesine sebep } \\
\text { olmuştur. } \\
\end{array}$ & $\begin{array}{l}\text { Fen ve teknoloji } \\
\text { dersinde bilgisayar } \\
\text { destekli animasyon } \\
\text { yönteminin } \\
\text { uygulanması } \\
\text { öğrencilerin } \\
\text { başarılarının } \\
\text { artmasına sebep } \\
\text { olmuştur. }\end{array}$ & $\begin{array}{l}\text { Fen ve teknoloji } \\
\text { dersinde proje tabanlı } \\
\text { öğrenme yaklaşımının } \\
\text { uygulanması } \\
\text { öğrencilerin } \\
\text { tutumlarının olumlu } \\
\text { yönde değişmesine, } \\
\text { bilimsel süreç } \\
\text { becerilerinin } \\
\text { artmasına sebep } \\
\text { olmuştur. Ancak } \\
\text { başarılarının anlamlı } \\
\text { bir şeklide } \\
\text { değişmesine sebep } \\
\text { olmamıştır. }\end{array}$ & $\begin{array}{l}\text { Akıllı Tahta ile } \\
\text { verilen eğitim } \\
\text { öğrencilerin } \\
\text { akademik } \\
\text { başarılarını } \\
\text { arttırmış ve derse } \\
\text { yönelik } \\
\text { tutumlarını } \\
\text { olumlu yönde } \\
\text { etkilemiştir. Fakat } \\
\text { öğrencilerin } \\
\text { motivasyonlarında } \\
\text { anlamlı bir } \\
\text { değişiklik } \\
\text { görülmemiştir. }\end{array}$ & 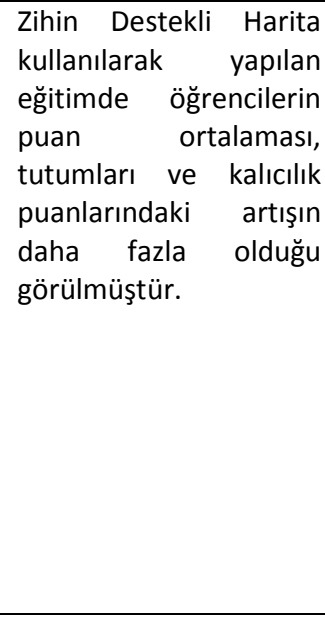 \\
\hline Yazar & Çetin, E.(2012) & Bastem, E.(2012) & Ayverdi, L. (2012) & Orhan, A. (2012) & Türkan, A. (2012) & Türksoy, E. (2012) & Ermiş, F. U.(2012) \\
\hline Örnek & $\begin{array}{lll}\text { 7.sınıf } & / \quad 64 \\
\text { öğrenci } & \end{array}$ & 6. sınıf / 77 öğrenci & 8. sınıf / 30 öğrenci & 6. sınıf / 40 öğrenci & $\begin{array}{l}\text { 7. sınıf / } 2 \text { ilköğretim } \\
\text { okulu öğrencileri }\end{array}$ & 5. sınıf / 121 öğrenci & 6. sınıf / 34 öğrenci \\
\hline
\end{tabular}


Saltan, Türkyılmaz, Karaçaltı \& Kemal Bilir - Çukurova Üniversitesi Eğitim Fakültesi Dergisi, 47(1), 2018, 308-336

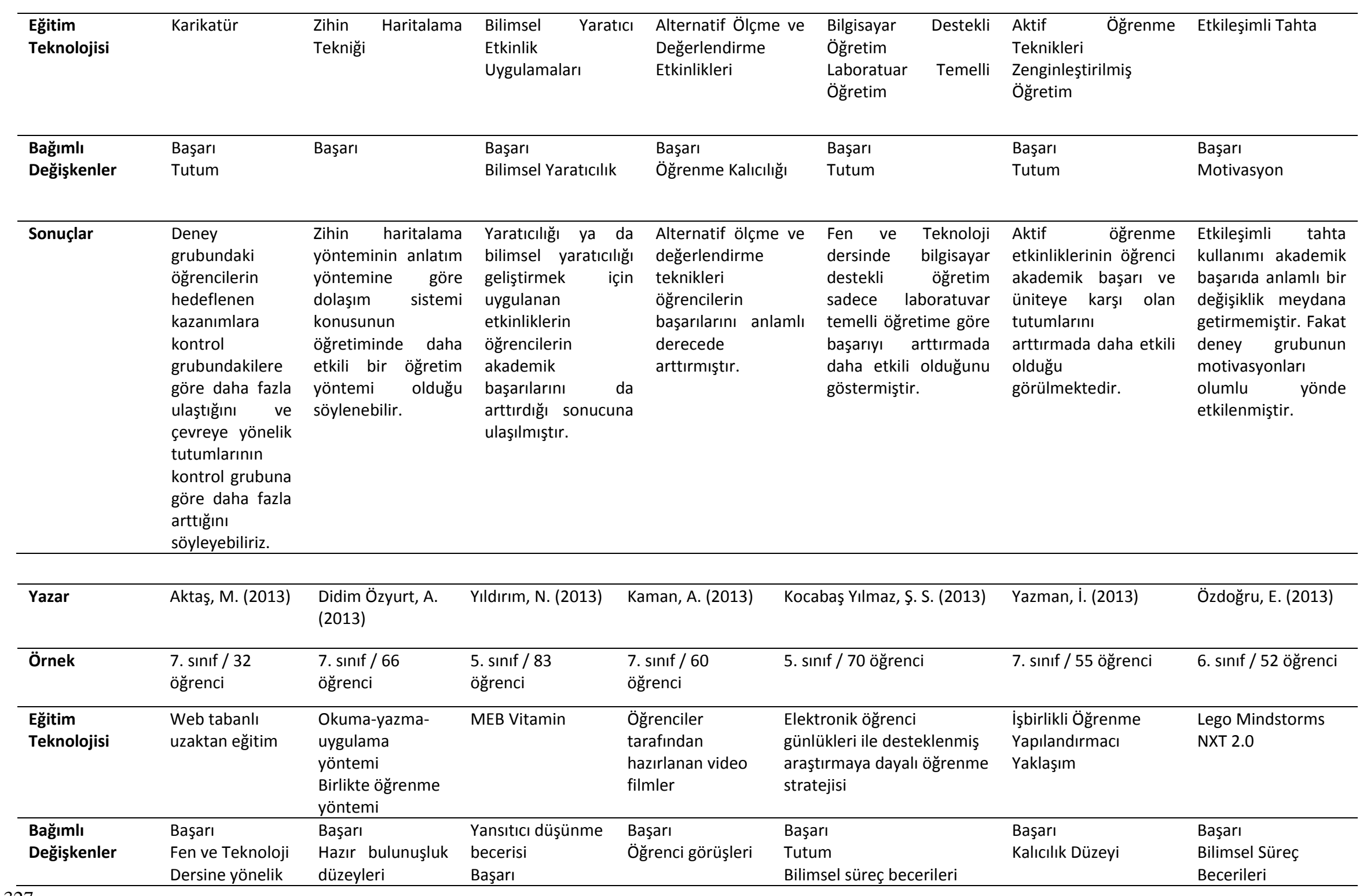


Saltan, Türkyılmaz, Karaçaltı \& Kemal Bilir - Çukurova Üniversitesi Eğitim Fakültesi Dergisi, 47(1), 2018, 308-336

\begin{tabular}{|c|c|c|c|c|c|c|c|c|}
\hline & $\begin{array}{l}\text { tutum } \\
\text { Bilgisayara } \\
\text { yönelik tutum }\end{array}$ & & & & & & & $\begin{array}{lr}\text { Fen Ve } & \text { Teknoloji } \\
\text { Dersine } & \text { Yönelik } \\
\text { Tutumları } & \\
\end{array}$ \\
\hline Sonuçlar & $\begin{array}{l}\text { Web tabanlı } \\
\text { uzaktan eğitimin } \\
\text { öğrencilerin fen } \\
\text { ve teknoloji } \\
\text { dersine yönelik } \\
\text { tutumlarında } \\
\text { anlamlı bir } \\
\text { farklılık } \\
\text { bulunamamasına } \\
\text { rağmen } \\
\text { bilgisayara } \\
\text { yönelik tutum } \\
\text { son-test puanları } \\
\text { arasında anlamlı } \\
\text { bir farklılık } \\
\text { bulunmuştur. }\end{array}$ & $\begin{array}{ll}\text { Fen ve teknoloji } & \\
\text { dersinde yer alan } & \text { e } \\
\text { beş farklı deneyin } & \text { ö } \\
\text { öğretiminin, } & d \\
\text { Okuma-Yazma- } & \text { ö } \\
\text { Uygulama, } & \text { a } \\
\text { Birlikte Öğrenme } & \text { b } \\
\text { ve Geleneksel } & \text { y } \\
\text { Öğretim } & \text { b } \\
\text { yöntemine göre } & d \\
\text { yürütülmesinin } & \text { o } \\
\text { öğrencilerin } & \\
\text { akademik } & \\
\text { başarılarına } & \\
\text { olumlu } & \text { etki } \\
\text { yaptığı } & \\
\text { görülmüştür. } & \\
\end{array}$ & $\begin{array}{l}\text { MEB vitamin } \\
\text { etkinliklerine bağlı } \\
\text { öğretim yapılan } \\
\text { deney grubu } \\
\text { öğrencilerinin } \\
\text { akademik } \\
\text { başarılarında ve } \\
\text { yansıtıcı düşünme } \\
\text { becerilerinde artış } \\
\text { daha fazla } \\
\text { olmuştur. }\end{array}$ & $\begin{array}{l}\text { Öğrenciler } \\
\text { tarafından } \\
\text { hazırlanan video } \\
\text { filmlerle yapılan } \\
\text { Fen ve } \\
\text { Teknoloji dersi } \\
\text { öğretiminin } \\
\text { öğrenci başarısını } \\
\text { artırmada etkili } \\
\text { olduğu } \\
\text { görülmüştür. }\end{array}$ & $\begin{array}{l}\text { Elektronik günlüklerle } \\
\text { desteklenmiş araştırmaya } \\
\text { dayalı öğrenme stratejisi ile } \\
\text { öğrenim gören öğrencilerin } \\
\text { akademik başarıları olumlu } \\
\text { yönde etkilenmiştir fakat } \\
\text { tutumlarında ve bilimsel } \\
\text { süreç becerilerinde anlamlı } \\
\text { bir farklılık yoktur. }\end{array}$ & $\begin{array}{l}\text { Yapılan analiz } \\
\text { sonucunda de } \\
\text { grubu ve kont } \\
\text { grubu son tes } \\
\text { puanları arası } \\
\text { kalııılık testi b } \\
\text { puanları arası } \\
\text { anlamlı bir far } \\
\text { saptanmamış } \\
\text { modeli daha } k \\
\text { bir etki göster }\end{array}$ & $\begin{array}{l}\text { y } \\
\text { I } \\
\text { aşarı } \\
\text { a ve } \\
\text { arı } \\
\text { a } \\
5 \mathrm{E} \\
\text { arılı } \\
\text { iştir. }\end{array}$ & $\begin{array}{l}\text { Lego Mindstorms } \\
\text { NXT } 2.0 \text { robot } \\
\text { kitlerinin } \\
\text { öğrencilerin } \\
\text { akademik } \\
\text { başarılarının artış } \\
\text { göstermesinde, } \\
\text { bilimsel süreç } \\
\text { becerilerinin } \\
\text { geliştirilmesi } \\
\text { konusunda ve } \\
\text { öğrencilerin } \\
\text { tutumlarında etkili } \\
\text { olduğu } \\
\text { görülmektedir. }\end{array}$ \\
\hline Yazar & Demirci, G. (2013) & Güneş, M. N. (2013) & Aktaş, S. (2015) & Demirci, E. (2016) & Çetin, Y.S. (2013) & Sayın, Ş. (2015) & Kele & 1. (2015) \\
\hline Örnek & 7. sınıf / 30 öğrenci & 7. sınıf / 84 öğrenci & 7. Sinıf & 7. Sinif & 6. Sinif & 7. Sinıf & 7. SII & \\
\hline $\begin{array}{l}\text { Eğitim } \\
\text { Teknolojisi }\end{array}$ & $\begin{array}{l}\text { Mizah ve Karikatür } \\
\text { Materyalleri }\end{array}$ & $\begin{array}{l}3 \text { Boyutlu Görsel } \\
\text { Materyaller }\end{array}$ & Akıllı Tahta & Öğrenci Günlükleri & $\begin{array}{l}\text { Animasyon ile } \\
\text { desteklenmiş } \\
\text { tahmin-gözlem- } \\
\text { açıkla Stratejisi }\end{array}$ & $\begin{array}{l}\text { Kavram } \\
\text { Karikatürleri }\end{array}$ & $\begin{array}{l}\text { Prob } \\
\text { yönt }\end{array}$ & $\begin{array}{l}\text { me dayalı öğrenme } \\
\text { ni }\end{array}$ \\
\hline $\begin{array}{l}\text { Bağımlı } \\
\text { Değişkenler }\end{array}$ & $\begin{array}{l}\text { Başarı } \\
\text { Motivasyon }\end{array}$ & $\begin{array}{l}\text { Başarı } \\
\text { Tutum } \\
\text { Kavram } \\
\text { Kalıcılık }\end{array}$ & $\begin{array}{l}\text { Başarı } \\
\text { Kalıcılık }\end{array}$ & $\begin{array}{l}\text { Başarı } \\
\text { Üst Biliş Becerileri }\end{array}$ & Başarı & $\begin{array}{l}\text { Başarı } \\
\text { Sorgulayıcı } \\
\text { öğrenme } \\
\text { becerileri } \\
\text { Motivasyon }\end{array}$ & $\begin{array}{l}\text { Başa } \\
\text { Kalıc }\end{array}$ & \\
\hline
\end{tabular}


Saltan, Türkyılmaz, Karaçaltı \& Kemal Bilir - Çukurova Üniversitesi Eğitim Fakültesi Dergisi, 47(1), 2018, 308-336

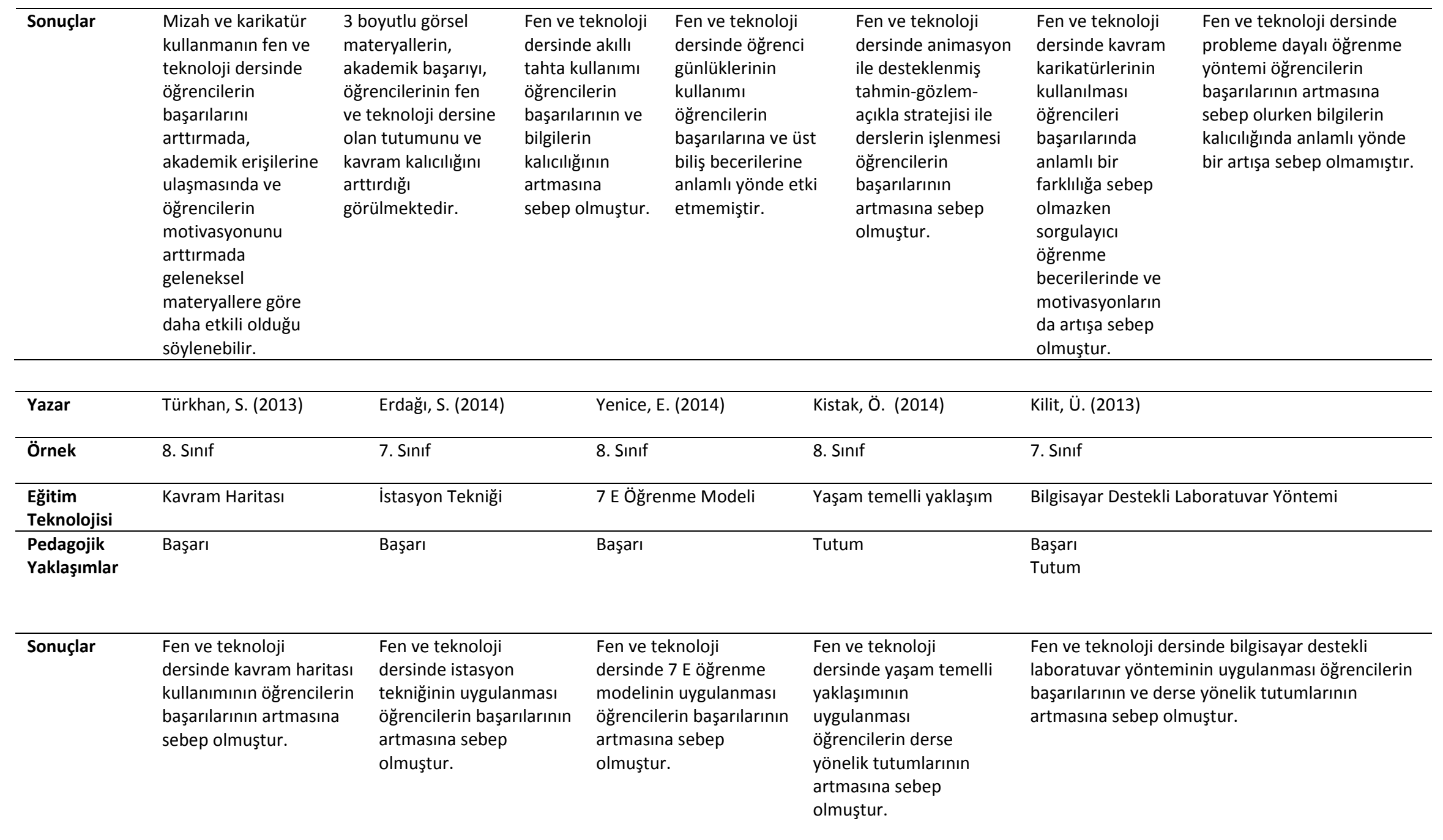




\section{Sonuçlar}

Eğitim Teknolojilerinin uygulanması Fen ve Teknoloji dersindeki akademik başarıyı etkilemeye yönelik bulgular?

Eğitim teknolojilerinin akademik başarıya olan etkisini incelemek amacıyla 43(\%91) tez incelenmiştir. Bulgulara göre incelenen tezlerin 41 tanesinde uygulanan eğitim teknolojileri bireylerin akademik başarılarında istatistiki açıdan anlamlı bir farklılık oluşturduğu görülmüştür. Geriye kalan 2 tezde ise öğrencilerin akademik başarılarında istatistiki açıdan anlamlı bir farklılık oluşturmadığı görülmüştür. Eğitim teknolojilerinin akademik başarıya olan etkisi Tablo 3' de gösterilmiştir.

Tablo3.

Eğitim teknolojilerinin Fen ve Teknoloji dersi akademik başarısına etkisi

\begin{tabular}{ll}
\hline İstatistiki Açıdan & $1,3,4,5,6,7,8,9,11,12,14,15,16,17,18,19,20,21,22,23,24,25,26,27,29$, \\
Anlamlı Farklılı & $30,31,32,33,35,36,37,38,39,40,41,42,43,44,45,47$ \\
$\begin{array}{l}\text { Anlamlı Olmayan } \\
\text { Farklılık }\end{array}$ & 28,34,
\end{tabular}

\section{Eğitim Teknolojilerinin uygulanması Fen ve Teknoloji dersindeki tutumu etkilemeye yönelik bulgular?}

Incelenen tezlerin 18(\%38)' sinde fen ve teknoloji dersinde kullanılan eğitim teknolojilerinin Fen ve Teknoloji dersi tutumuna yönelik etkisine bakılmıştır.17 tezden 15 tanesinde öğrencilerin fen ve teknoloji dersine yönelik tutumlarında anlamlı farklılık oluştuğu görülmüştür. 3 tezde ise öğrencilerin tutumlarında istatistiki açıdan anlamlı bir farklıık oluşmadığı görülmüştür.

Tablo4.

Eğitim teknolojilerinin Fen ve Teknoloji dersine karşı olan tutumuna etkisi

\begin{tabular}{ll}
\hline İstatistiki Açıdan & $3,4,7,8,9,11,14,17,19,20,21,26,29,35,37,47$ \\
Anlamlı Farklıık & \\
Anlamlı Olmayan & $1,13,33$ \\
Farklılık &
\end{tabular}

Eğitim Teknolojilerinin uygulanması Fen ve Teknoloji dersine ait bilgi kalıcılığını etkilemeye yönelik bulgular?

Incelenen tezlerin $9(\% 20)$ tanesinde eğitim teknolojilerinin fen ve teknoloji dersinde öğrenilen bilgilerin kalıcılığına etkisi araştırılmıştır. Bulgulara göre tezlerden 7 tanesinde öğrenilen bilgilerin kalıcılığında anlamlı farklııık oluşturduğu görülmüştür. Diğer 2 tezde ise bilgilerin kalıcılığında anlamlı farklılık oluşmadığı görülmüştür.

Tablo5.

Eğitim teknolojilerinin Fen ve Teknoloji dersine ait bilgi kalıcılığına etkisi

\begin{tabular}{ll}
\hline İstatistiki Açıdan & $5,6,8,20,24,36,37$ \\
Anlamlı Farklılık & \\
Anlamlı Olmayan & 33,41 \\
Farklılık &
\end{tabular}

Eğitim Teknolojilerinin uygulanması Fen ve Teknoloji dersindeki bilimsel süreç başarılarını etkilemeye yönelik bulgular?

Incelenen tezlerin 9(\%19) tanesinde eğitim teknolojilerinin bilimsel süreç becerilerine olan etkisi incelenmiştir. Bulgulara göre tezlerden 7 tanesinde öğrencilerin bilimsel süreç becerilerinde anlamlı bir farklılık oluşurken geri kalan 2 tezde anlamlı bir farklılık oluşmadığı görülmüştür. 
Tablo6.

Eğitim teknolojilerinin Fen ve Teknoloji dersindeki bilimsel süreç becerilerine etkisi

\begin{tabular}{ll}
\hline İstatistiki Açıdan & $3,5,7,8,10,19,35$ \\
Anlamlı Farklılık & \\
$\begin{array}{l}\text { Anlamlı Olmayan } \\
\text { Farklılık }\end{array}$ & 17,33
\end{tabular}

\section{Incelenen tezlerde kullanılan araştırma desenleri}

Listelenen tezlerin $41(\% 89)$ tanesinde eğitim teknolojilerinin etkililiğini belirlemek amacıyla yarı deneysel yöntem kullanılmıştır. 5 tanesinde hem nitel yöntemin hem de nicel yöntemin bir arada kullanıldığı karma yöntem kullanılmıştır. Karma yöntem kullanılan 3 tezde nitel yöntem olarak yarı deneysel yöntem, nicel yöntem için ise betimsel yöntem kullanılırken geriye kalan 2 tezde ise nicel yöntem aşamasında durum çalışması kullanılmıştır. Tezlerde kullanılan araştırma desenleri Tablo 7’ de gösterilmiştir.

\section{Tablo7.}

Araştırma desenleri

\begin{tabular}{ll}
\hline Araştırma Desenleri & Tezler \\
\hline & $1,3,4,5,6,8,9,10,11,12,13,14,15,16,17,20,21$, \\
Yarı deneysel yöntem & $22,23,25,27,28,29,30,31,32,33,34,35,36,37$, \\
& $38,39,40,41,42,43,44,45,46$ \\
Karma yöntem (yarı deneysel - betimsel) & $2,18,19$ \\
Karma yöntem (yarı deneysel - durum çalışması) & 7,24 \\
\hline
\end{tabular}

\section{İncelenen tezlerde kullanılan veri toplama araçları}

İncelenen tezlerde eğitim teknolojilerinin fen teknoloji dersinde kullanılmasının çeşitli (tutum/akademik başarı vb.) değişkenlere etkisini belirlemek amacıyla kullanılan veri toplama araçları test, ölçek ve açık uçlu soru başlıkları altında toplanmıştır. Birçok çalışmada birden fazla veri toplama aracı kullanılmıştır. Bu bağlamda belirlenen veri toplama araçları Tablo 8' de gösterilmiştir.

Tablo8.

Veri toplama araçları

\begin{tabular}{ll}
\hline Veri Toplama Araçları & Tezler \\
\hline \multirow{2}{*}{ Test (Başarı/Kalıcılık) } & $1,2,3,4,5,6,7,8,9,10,11,13,14,15,16,17$, \\
& $18,19,20,22,23,24,25,26,27,28,29,30,31,32$, \\
Ölçek (Tutum/Motivasyon vb.) & $33,34,36,37,38,40,41,42,43,44,45,46$. \\
Açık Uçlu & $1,3,4,7,8,10,11,12,13,16,18,19,20,21,25,27$, \\
& $28,32,334$ \\
\end{tabular}




\section{Tartışma ve Öneriler}

Bu çalışmada eğitim teknolojilerinin fen ve teknoloji derslerinde kullanılması ile öğrencilerin derse yönelik akademik başarısını, tutumunu, bilgi kalıcılığını ve bilimsel süreç becerilerine olan etkisi incelenmiştir. Tarama çalışmasının örneklemini Türkiye de yürütülen son beş yıl (2012-2016) da yayımlanan fen ve teknoloji dersi ile ilgili 12 doktora tezi ve 34 tane yüksek lisans tezi olmak üzere toplamda 46 tez oluşturmaktadır. Çalışmada listelenen tezler incelendiğinde; tezlerin genelinde (\%89) yarı deneysel yöntem kullanıldığı, az da olsa karma yönteminde tercih edildiği görülmektedir. Bu yöntemlerin kullanıldığı tezlerde ise veri toplama aracı olarak başarı ve kalıcılık testleri, tutum, motivasyon vb. ölçekleri ve açık uçlu sorular kullanıldığı görülmektedir. Özellikle son on yılda eğitim alanında yürütülen çalışmalarda nicel paradigmadan nitel paradigmaya geçiş yaşandığı konuşulmaktadır. Oysa ki bu tarama çalışmasının sonucu bunu doğrulamamaktadır. Görüldüğü üzere her on çalışmadan dokuzunda yarı deneysel metot kullanılmıştır. Bunun yanı sıra motivasyon ve tutum çalışmaları güncelliklerini korumaktadır.

Çalışmanın bulguları incelendiğinde akademik başarı için listelenen tezlerin büyük çoğunluğunda (\%91) öğrencilerin akademik başarılarında istatistiki açıdan anlamlı bir farklılık olduğu görülmektedir. Aynı şekilde öğrencilerin fen ve teknoloji dersi tutumuna olan etkisini incelendiğimizde, listelenen tezlerin yarıdan fazlasında (\%78) istatistiki açıdan anlamlı farklılık oluşturduğu görülmektedir. Bu sonuca göre eğitim teknolojilerinin fen ve teknoloji dersinde kullanılması öğrencilerin bu dersteki akademik başarılarını ve tutumlarını olumlu yönde etkilediği sonucuna varılabilir. Bu durumun nedeni, soyut kavramların yer aldığı ve karmaşık konuların bulunduğu fen derslerinde eğitim teknolojilerinin uygulanması öğretim ortamını zenginleştirdiği ve birden fazla duyu organına hitap ederek kalıcılığı sağladığı gösterilebilir(Kahyaoğlu,2011). Bacanak, Değirmenci, Karamustafaoğlu ve Karamustafaoğlu (2011) tarafından yürütülen tarama çalışmasında fen eğitimi alanında yürütülen çalışmalarda kullanılan yöntemler incelenmiş ve deneysel çalışmaların çoğunlukta olduğu vurgulanmıştır.

Anlamlı farklılığın görüldüğü bir başka alan ise teknolojinin bilgi kalıcılığına olan etkisidir. Taranan çalışmaların yarıdan fazlasında (\%77) fen ve teknoloji derslerinde eğitim teknolojilerinin kullanılması kalıcılığı sağladığı görülmüştür. Bu bulgular eğitim teknolojilerinin fen eğitiminde kullanılması ile bilginin kalıcılığının sağlandığı ve akademik başarıyı desteklediği görülmektedir. Bu sonuç fen ve teknoloji derslerinde ses, video, animasyon, benzetim gibi eğitim teknolojilerinin kullanılmasının önemini ortaya çıkarmıştır. Bunlar bilginin kalıcılığı ve akademik başarı açısından geleneksel yönteme göre daha etkili olduğu görülmüştür. İncelenen çalışmaların yaklaşık beşte dördü teknoloji kullanımın fen eğitiminde anlamlı bir etkiye sahip olduğunu ortaya koymaktadır.

Araştırmada yer alan bilimsel süreç becerilerinin listelenen tezlerin büyük çoğunluğunda (\%77) anlamlı farklılık oluşturduğu görülmektedir. Bu sonuca göre, fen ve teknoloji derslerinin bilimsel süreç becerilerine (deney yapma, verileri yorumlama, hipotez kurma vb.) göre yürütülmesi geleneksel yönteme göre daha başarılı olduğu görülmektedir. Bilimsel süreçle ilgili yapılmış çalışmalar incelendiğinde benzer sonuçların bulunduğu görülmüştür (Geban,1990; Arslan,1995; Ercan,1996; Doğruöz,1998; Temiz, 2001). Diğer yandan Ercan 1996 yılında yaptığı çalışmada öğretmenlere göre, fen ve teknoloji dersleri için ayrılan zaman, sınıfların kalabalık olması, ders içeriğinin fazla olması, laboratuvar eksikliği veya araç gereç eksikliği gibi faktörlerin bilimsel süreç becerilerinin gelişmesini olumsuz yönde etkilediğini söylemektedir.

Tüm bu sonuçlardan yola çıkarak şunları söyleyebiliriz; Sunulan çalışma alan yazında eğitim teknolojileri kullanımının fen eğitiminde anlamlı bir etkiye sahip olduğunu gösteriyor. Fen eğitiminin yürütüldüğü tüm kademelerde teknoloji desteğinin artırılmasında fayda olacağı bu sonuçlardan çıkarılabilir. Özellikle "STEM" yaklaşımı düşünüldüğünde fen, matematik ve mühendisliğin yanında teknoloji kullanımı gelecek yıllarda ilk ve orta öğretimde daha da önem kazanacaktır. İyi yetişmiş insan gücünün en büyük dinamizmi olan ülkemizde fen eğitiminin teknoloji ile barışık, omuz omuza yürütülmesi çok önemli bir kazanç olacaktır. Öte yandan Eğitim Fakültelerimizde Fen bilimleri öğretmelerimiz yetişirken bu yaklaşımın takip edilmesi, onlarında göreve başladıklarında benzer etkinliklerle öğretim yapacaklarını sonucunu doğuracaktır. Bu sayede akademik başarı, tutum ve kalıcılık açısından önemli kazançlar sağlanabilir. Son söz olarak çalışmanın bulguları hem öğretmenleri hem de eğitim fakültelerinde görev yapan öğretim üyelerini fen eğitimini teknoloji destekli verme konusunda teşvik etmektedir. 


\section{References}

Aktaş, M. (2013).Fen ve teknoloji dersinde web tabanlı uzaktan eğitimin öğrencilerin akademik başarı ve tutumları üzerindeki etkisi. Unpublished master's thesis, Bülent Ecevit Üniversitesi Sosyal Bilimler Enstitüsü, Zonguldak. (345326)

Aktaş, S. (2015).Fen ve teknoloji dersinde akıllı tahta kullanımının öğrencilerin akademik başarısına ve bilgilerin kalıcılığına etkisi. Unpublished master's thesis, Kastamonu Üniversitesi Fen Bilimleri Enstitüsü, Kastamonu.

Arslan, A. (1995).ilkokul Öğrencilerinde Gözlemlenen Bilimsel Beceriler. Unpublished doctorate dissertation, Hacettepe Üniversitesi Sosyal Bilimler Enstitüsü, Ankara.

Arksey, H. \& O'Malley, L. (2005). Scopingstudies: Towards a Methodological Framework. International Journal of Social Research Methodology, 8(1), 19-32.

Aşiroğlu, S. (2014).Aktif Öğrenme Temelli Fen ve Teknoloji Dersi Etkinliklerinin 5. Sınıf Öğrencilerinin Problem Çözme Becerileri ve Başarıları Üzerinde Etkisi. Unpublished doctorate dissertation, İnönü Üniversitesi Eğitim Bilimleri Enstitüsü, Malatya.

Ayverdi, L. (2012).ilköğretim 8. sınıf fen ve teknoloji dersinde bilimsel yaratıcı etkinlik uygulamaları: "Hücre Bölünmesi ve Kalıtım" ünitesi örneği. Unpublished master's thesis, Balıkesir Üniversitesi Fen Bilimleri Enstitüsü, Balıkesir.

Bacanak, A., Değirmenci, S., Karamustafaoğlu, S. \& Karamustafaoğlu, O. (2011). E-dergilerde Yayınlanan Fen Eğitimi Makaleleri: Yöntem Analizi, Türk Fen Eğitimi Dergisi, 8(1), 119-132.

Bal, M.S. \& Karademir, N. (2013). Sosyal bilgiler öğretmenlerinin teknolojik pedagojik alan bilgisi (TPAB) konusunda öz-değerlendirme seviyelerinin belirlenmesi. Pamukkale Üniversitesi Eğitim Fakültesi Dergisi, 34(2), 15-32.

Bastem, E. (2012).6. Sınıf fen ve teknoloji dersinde dolaşım sistemi konusunun zihin haritalama tekniği ile öğretilmesinin başarıya etkisi. Unpublished master's thesis, Atatürk Üniversitesi Eğitim Bilimleri Enstitüsü, Erzurum.

Çakar, E. (2013).Fen ve Teknoloji Dersinde Araştırmaya Dayalı Öğrenmenin Öğrencilerin Erişilerine, Kavram Öğrenmelerine, Üst biliş Farkındalıklarına ve Fen ve Teknoloji Dersine Yönelik Yönelik Tutumlarına Etkisi. Unpublished doctorate dissertation, Ege Üniversitesi Sosyal Bilimler Enstitüsü, İzmir

Çelik, K. (2012).Canlılarda üreme, büyüme ve gelişme ünitesinin araştırmaya dayalı öğrenme yöntemi ile işlenmesinin öğrencilerin akademik başarılarına, bilimsel süreç becerilerine ve fen ve teknoloji dersine yönelik tutumlarına etkisi. Unpublished master's thesis, Dokuz Eylül Üniversitesi Eğitim Bilimleri Enstitüsü, İzmir.

Çetin, E. (2012).Karikatürler ile zenginleştirilmiş fen ve teknoloji dersinin öğrenci başarısı ve tutumları üzerine etkisi. Unpublished master's thesis, Selçuk Üniversitesi Eğitim Bilimleri Enstitüsü, Konya.

Çetin, Y. S. (2013).Ortaokul 2. sınıf fen ve teknoloji dersi solunum sistemi konusunun öğretiminde animasyonlarla desteklenmiş "Tahmin-Gözlem-Açıklama" stratejisinin öğrenci başarısına etkisi. Unpublished master's thesis, Atatürk Üniversitesi Eğitim Bilimleri Enstitüsü, Erzurum.

Daşdemir, i. (2012).ilköğretim Fen ve Teknoloji Dersinde Animasyon Kullanımının Öğrencilerin Akademik Başarılarına, Öğrenilen Bilgilerin Kalıcılığına ve Bilimsel Süreç Becerilerine Etkisi. Unpublished doctorate dissertation, Atatürk Üniversitesi Eğitim Bilimleri Enstitüsü, Erzurum.

Demirci, E. (2015).ilköğretim 7. sınıf fen ve teknoloji dersi yaşamımızdaki elektrik ünitesinde öğrenci günlüklerinin kullanımının öğrencilerin üst bilişsel beceri gelişimine ve başarılarına etkisi. Unpublished master's thesis, Pamukkale Üniversitesi Eğitim Bilimleri Enstitüsü, Denizli.

Demirci, G. (2013).Eğitimde mizah ve karikatür kullanımının öğrenci başarısı ve motivasyonuna etkisi (ortaokul 7. sınıf fen ve teknoloji dersi örneği). Unpublished master's thesis, Gazi Üniversitesi Eğitim Bilimleri Enstitüsü, Ankara.

Demirçalı, S. (2012).7. Sınıf Fen ve Teknoloji Dersi "Insan ve Çevre" Ünitesinde Fen-Teknoloji-Toplum Yaklaşımıyla Öğretim Sonuçlarının Değerlendirilmesi. Unpublished doctorate dissertation, Gazi Üniversitesi Eğitim Bilimleri Enstitüsü, Ankara. 
Dirim Özyurt, A. (2013).Fen ve teknoloji dersinin uygulamalarında işbirlikli öğrenme modelinin öğrencilerin akademik başarısına etkisi. Unpublished master's thesis, Atatürk Üniversitesi Eğitim Bilimleri Enstitüsü, Erzurum.

Doğruöz, P. (1998).Bilimsel İşlem Becerilerini Kullanmaya Yönelik Yöntemin Öğrencilerin Akışkanların Kaldırma Kuvveti Konusunu Anlamalarına Etkisi. Unpublished master's thesis, Orta Doğu Teknik Üniversitesi Fen Bilimleri Enstitüsü, Ankara.

Erdağı, S. (2014).istasyon tekniğinin fen ve teknoloji dersinin akademik başarısına etkisi. Unpublished master's thesis, Kafkas Üniversitesi Fen Bilimleri Enstitüsü, Kars.

Erdemir, N. (2012).ilköğretim 8. sınıf fen ve teknoloji dersi "canlılar ve enerji iliskileri" ünitesinin öğretiminde kullanılan animasyon yönteminin ögrrenci başarısına etkisi. Unpublished master's thesis, Yüzüncü Yıl Üniversitesi Fen Bilimleri Enstitüsü, Van.

Erdoğan, M. (2007). Yeni geliştirilen dördüncü ve beşinci sınıf fen ve teknoloji dersi öğretmen programının analizi: Nitel bir çalışma. Türk Eğitim Bilimleri Dergisi Bahar, 5(2), 221-254.

Ercan, E. B. (1996).4. ve 5. Sınıfta Bilimsel iş̧lem Becerilerinin Geliştirilmesine Dair Öğretmen Algıları. Unpublished master's thesis, Orta Doğu Teknik Üniversitesi Sosyal Bilimler Enstitüsü, Ankara.

Ermiş, F. U. (2012).Fen ve teknoloji dersinde etkileşimli tahta kullanımının akademik başarı ve öğrenci motivasyonuna etkisi. Unpublished master's thesis, Gazi Üniversitesi Eğitim Bilimleri Enstitüsü, Ankara.

Esmer Orunlu, E. (2012).ilköğretim 7. Sınıf fen ve teknoloji dersi karışımlar konusunun öğretiminde işbirlikli öğrenme yönteminin öğrencilerin başarılarına etkisi. Unpublished master's thesis, Gazi Üniversitesi Eğitim Bilimleri Enstitüsü, Ankara.

Fidan, K. E. (2012).Fen ve teknoloji dersinde bilgisayar destekli zihin haritası oluşturmanın öğrencilerin akademik başarııına, tutumlarına ve kalıcılığa etkisi. Unpublished master's thesis, Fırat Üniversitesi Eğitim Bilimleri Enstitüsü, Elazı̆̆.

Geban, Ö. (1990).iki Farkı Öğretim Yönteminin Lise Seviyesindeki Öğrencilerin Kimya Başarılarına, Bilimsel Işlem Becerilerine ve Kimyaya Karşı Olan Tutumlarına Etkisi. Unpublished master's thesis Orta Doğu Teknik Üniversitesi Fen Bilimleri Enstitüsü, Ankara.

Güçlüer, E. (2012).Fen ve Teknoloji Dersinde "Vücudumuzda Sistemler" Ünitesinde Fen Okuryazarlığını Geliştirici Etkinliklerin Kullanılmasının Başarıya, Tutuma ve Bilimsel Süreç Becerilerine Etkisi. Unpublished doctorate dissertation, Dokuz Eylül Üniversitesi Eğitim Bilimleri Enstitüsü, İzmir.

Güneş, M. N. (2013).ilköğretim fen ve teknoloji dersinde 3 boyutlu görsel materyal kullanımının başarıya, kavram ögrrenmeye ve tutuma etkisi. Unpublished master's thesis, Marmara Üniversitesi Eğitim Bilimleri Enstitüsü, İstanbul.

Gürbüz, F. (2012).7E Öğrenme Modelinin 6. Sınıf Fen ve Teknoloji Dersi "Yaşamımızdaki Elektrik" Ünitesinde Ögrrencilerin Akademik Başarılarına ve Kalıcılığa Etkisi. Unpublished doctorate dissertation, Atatürk Üniversitesi Eğitim Bilimleri Enstitüsü, Erzurum.

Jimoyiannis, A. \& Komis, V. (2001). ComputerSimulations in PhysicsTeachingand Learning: A Case Study on Students' Understanding of Trajectory Motion. Computerand Education, 36(2), 183-204.

Kahyaoğlu, M. (2011). İlköğretim Öğretmenlerinin Fen ve Teknoloji Dersinde Yeni Teknolojileri Kullanmaya Yönelik Görüşleri. Eğitim Bilimleri Araştırma Dergisi, 1(1), 79-96.

Kaman, A. (2013).Öğrenciler tarafından hazırlanan video filmlerin fen ve teknoloji dersi öğretiminde başarıya etkisi. Unpublished master's thesis, Gazi Üniversitesi Eğitim Bilimleri Enstitüsü, Ankara.

Karamustafaoğlu, O. (2009). Fen ve Teknoloji Eğitiminde Temel Yönelimler, Kastamonu Eğitim Dergisi, 17(1), 87-102.

Keleş, M. (2015).Fen ve teknoloji dersinin işlenişinde probleme dayalı öğrenme yönteminin öğrenci başarılarına ve öğrendiklerini hatırlama düzeylerine etkisi. Unpublished master's thesis, Necmettin Erbakan Üniversitesi Eğitim Bilimleri Enstitüsü, Konya.

Kılıç, M. A. (2013).Jigsaw tekniğinin 6.sınıf fen ve teknoloji dersi maddenin tanecikli yapısı ünitesinin öğretiminde öğrenci başarısına etkisi. Unpublished master's thesis, Gazi Üniversitesi Eğitim Bilimleri Enstitüsü, Ankara. 
Kilit, Ü. (2013).Fen ve Teknoloji dersi "Maddenin Değişimi ve Tanınması" ünitesinde bilgisayar destekli laboratuar yönteminin ortaokul 1. Sınıf öğrencilerinin akademik başarı ve fene yönelik tutumlarına etkisi. Unpublished master's thesis, Muğla Sıtkı Koçman Üniversitesi Eğitim Bilimleri Enstitüsü, Muğla.

Kistak, Ö. (2014).ilköğretim 8. sınıf fen ve teknoloji dersi ses ünitesinin yaşam temelli yaklaşımla öğretimi. Unpublished master's thesis, Balıkesir Üniversitesi Fen Bilimleri Enstitüsü, Balıkesir.

Kocabaş Yılmaz, Ş. S. (2013).Elektronik günlüklerle desteklenmiş araştırmaya dayalı fen ve teknoloji dersinin öğrencilerin öğrenme ürünlerine etkisi. Unpublished master's thesis, Akdeniz Üniversitesi Eğitim Bilimleri Enstitüsü, Antalya.

Koehler, M.J. \& Mishra, P.(2009). What is technological pedagogical content knowledge? Contemporary Issues in Technology and Teacher Education, 9(1), 60-70.

Moher, D., Liberati, A., Tetzlaff, J., Altman, D. G., \& PrismaGroup. (2009). Preferred reporting items for systematicr eviews and meta-analyses: the PRISMA statement. Plos Medicine, 6(7), e1000097.

Orhan, A. (2012).Alternatif ölçme ve değerlendirme etkinliklerinin 6. sınıf fen ve teknoloji dersi yaşamımızdaki elektrik ünitesindeki öğrenci başarısına etkisi. Unpublished master's thesis, Ahi Evran Üniversitesi Fen Bilimleri Enstitüsü, Kırşehir.

Özahioğlu, B. (2012).ilköğretim fen ve teknoloji dersinde proje tabanlı öğrenmenin bilimsel süreç becerilerine, başarı ve tutum üzerine etkisi. Unpublished master's thesis, Çanakkale Onsekiz Mart Üniversitesi Eğitim Bilimleri Enstitüsü, Çanakkale.

Özdemir, M. (2012).Illköğretim 5. Sınıf Fen ve Teknoloji Dersi Ünitelerinde Kavramsal Değişim Yaklaşımının Öğrenci Başarısına Etkisinin Incelenmesi. Unpublished doctorate dissertation, Gazi Üniversitesi Eğitim Bilimleri Enstitüsü, Ankara.

Özdoğru, Eda. (2013).Fiziksel olaylar öğrenme alanı için lego program tabanlı fen ve teknoloji eğitiminin öğrencilerin akademik başarılarına, bilimsel süreç becerilerine ve fen ve teknoloji dersine yönelik tutumlarına etkisi. Unpublished master's thesis, Dokuz Eylül Üniversitesi Eğitim Bilimleri Enstitüsü, İzmir.

Özer, M. (2012).Fen ve Teknoloji dersinde geleneksel öğretim yöntemi ile bilgisayar destekli öğretim yöntemlerinin öğrenci başarısına etkisi. Unpublished master's thesis, Fırat ÜniversitesiEğitim Bilimleri Enstitüsü, Elazığ.

Öztürk, N. (2013).6. Sınıf Fen ve Teknoloji Dersi Işık ve Ses Ünitesinde 5E Öğrenme Modeline Dayalı Etkinliklerin Öğrenme Ürünlerine Etkisi. Unpublished doctorate dissertation, Gazi Üniversitesi Eğitim Bilimleri Enstitüsü, Ankara.

Parsa, M. K. (2016).Iş̧birlikli Sorgulamaya Dayalı Öğrenme Ortamının Yaratıcı, Düşünmeye, Sorgulayıcı Öğrenme Becerilerine, Fen ve Teknoloji Dersine Yönelik Tutuma Etkisi. Unpublished doctorate dissertation, Marmara Üniversitesi Eğitim Bilimleri Enstitüsü, İstanbul

Sayın, Ş. (2015).ilköğretim fen ve teknoloji dersi 7. sınıf 'ışık' ünitesinin öğretiminde kavram karikatürleri kullanımının öğrencilerin akademik başarıları, sorgulayıcı öğrenme becerileri algıları ve motivasyonları üzerine etkisi. Unpublished master's thesis, Celal Bayar Üniversitesi Fen Bilimleri Enstitüsü, Manisa.

Shulman, L. S. (1986). ThoseWhoUnderstand: Knowledge Growth in Teaching. Educational Researcher, 15 (2), 4-14.

Sünkür, M. Ö. (2013).Fen ve Teknoloji Dersinde Tahmin Et- Gözle- Açıkla Yöntemi ile Desteklenmiş Yansıtıcı Düşünmeye Dayalı Etkinlik Uygulamalarının Değerlendirilmesi. Unpublished doctorate dissertation, İnönü Üniversitesi Eğitim Bilimleri Enstitüsü, Malatya.

Sever, D. (2012).ilköğretim Fen ve Teknoloji Dersinde Araştırma Temelli Öğrenme Yaklaşımının Öğrenci Dirençlerine Etkisi. Unpublished doctorate dissertation, Anadolu Üniversites/ Eğitim Bilimleri Enstitüsü, Eskişehir.

Temiz, B. K. (2001). Lise 1. Sınıf Fizik Dersi Programının Öğrencilerin Bilimsel Süreç Becerilerini Geliştirmeye Uygunluğunun Incelenmesi. Unpublished master's thesis, Gazi Üniversitesi Eğitim Bilimleri Enstitüsü, Ankara.

Tercan, i. (2012).Akılı tahta kullanımının öğrencilerin fen ve teknoloji dersi başarı, tutum ve motivasyonuna etkisi. Unpublished master's thesis, Necmettin Erbakan Üniversitesi Eğitim Bilimleri Enstitüsü, Konya. 
Türkan, A. (2012).ilköğretim 7.sınıf fen ve teknoloji dersi kuvvet ve hareket ünitesinde bilgisayar destekli ve laboratuvar temelli öğretimin öğrencilerin akademik başarı ve tutumlarına etkisinin karşılaştırılması. Unpublished master's thesis, Niğde Üniversitesi Eğitim Bilimleri Enstitüsü, Niğde.

Türkhan, S. (2013).ilköğretim 8. sınıf fen ve teknoloji dersi periyodik cetvel konusunda kavram haritası kullanımının öğrencilerin başarısına etkisi. Unpublished master's thesis, Uşak Üniversitesi Sosyal Bilimler Enstitüsü, Uşak.

Türksoy, E. (2012).ilköğretim 5. sınıf fen ve teknoloji dersinde aktif öğrenme teknikleri ile zenginleştirilmiş öğretimin öğrencinin akademik başarıları ve tutumları üzerine etkisi. Unpublished master's thesis, Mehmet Akif Ersoy Üniversitesi Sosyal Bilimler Enstitüsü, Burdur.

Uyanık, G. (2014).ilkokul dördüncü sınıf fen ve teknoloji dersinde kavramsal değişim yaklaşımının etkililiğinin incelenmesi. Unpublished doctorate dissertation, Gazi Üniversitesi Eğitim Bilimleri Enstitüsü, Ankara.

Yazman, i. (2013).Iş̧birlikli Jigsaw tekniği ve 5e modeliyle öğretimin 7.sınıf öğrencilerinin fen ve teknoloji dersinde yayları tanıyalım ile iş ve enerji konularındaki başarılarına ve kalıcılık düzeylerine etkisi. Unpublished master's thesis, Kafkas Üniversitesi Fen Bilimleri Enstitüsü, Kars.

Yenice, E. (2014).Yapılandırmacı yaklaşımın 7e öğrenme modelinin 8.sınıf fen ve teknoloji dersi "mitoz ve mayoz bölünme" konusunda öğrencilerin akademik başarılarına etkisinin incelenmesi. Unpublished master's thesis, Kafkas Üniversitesi Fen Bilimleri Enstitüsü, Kars.

Kurt, Y. (2012).5E Modelinin Illköğretim 6. Sınıf öğrencilerinin fen ve teknoloji dersine ilişkin akademik başarı ve tutumlarına etkisi. Unpublished master's thesis, Mehmet Akif Ersoy Üniversitesi Sosyal Bilimler Enstitüsü, Burdur.

Yıldırım, N. (2013).Ortaokul 5. sınıf fen ve teknoloji dersinde kullanılan meb vitamin eğitim yazılımının öğrencilerin yansıtıcı düşünme becerilerine ve erişilerine etkisinin incelenmesi. Unpublished master's thesis, Necmettin Erbakan Üniversitesi Eğitim Bilimleri Enstitüsü, Konya. 